\title{
THE PILLARS OF POTENTIAL GROWTH AND THE ROLE OF POLICY: A PANEL DATA APPROACH
}

Matteo Lanzafame, Jesus Felipe, Noli Sotocinal, and Connie Bayudan-Dacuycuy

NO. 482

May 2016
ADB ECONOMICS WORKING PAPER SERIES 


\section{ADB Economics Working Paper Series}

\section{The Pillars of Potential Growth and the Role of Policy: A Panel Data Approach}

Matteo Lanzafame, Jesus Felipe, Noli Sotocinal, and Connie Bayudan-Dacuycuy

No. 482 | May 2016
Matteo Lanzafame (mlanzafame@unime.it) is associate professor in Political Economy at the University of Messina; Jesus Felipe (jfelipe@adb.org) is advisor, Noli Sotocinal (nsotocinal@adb.org) is senior economics officer at the Economic Research and Regional Cooperation Department of the Asian Development Bank; Connie Bayudan-Dacuycuy (cdacuycuy@ateneo.edu) is assistant professor in the Department of Economics at the Ateneo de Manila University. 
Asian Development Bank

6 ADB Avenue, Mandaluyong City

1550 Metro Manila, Philippines

www.adb.org

(C) 2016 by Asian Development Bank

May 2016

ISSN 2313-6537 (Print), 2313-6545 (e-ISSN)

Publication Stock No. WPS168073-2

The views expressed in this paper are those of the authors and do not necessarily reflect the views and policies of the Asian Development Bank (ADB) or its Board of Governors or the governments they represent.

ADB does not guarantee the accuracy of the data included in this publication and accepts no responsibility for any consequence of their use.

By making any designation of or reference to a particular territory or geographic area, or by using the term "country" in this document, $A D B$ does not intend to make any judgments as to the legal or other status of any territory or area.

Note: In this publication, "\$" refers to US dollars.

The ADB Economics Working Paper Series is a forum for stimulating discussion and eliciting feedback on ongoing and recently completed research and policy studies undertaken by the Asian Development Bank (ADB) staff, consultants, or resource persons. The series deals with key economic and development problems, particularly those facing the Asia and Pacific region; as well as conceptual, analytical, or methodological issues relating to project/program economic analysis, and statistical data and measurement. The series aims to enhance the knowledge on Asia's development and policy challenges; strengthen analytical rigor and quality of ADB's country partnership strategies, and its subregional and country operations; and improve the quality and availability of statistical data and development indicators for monitoring development effectiveness.

The ADB Economics Working Paper Series is a quick-disseminating, informal publication whose titles could subsequently be revised for publication as articles in professional journals or chapters in books. The series is maintained by the Economic Research and Regional Cooperation Department. 


\section{CONTENTS}

TABLES AND FIGURES

ABSTRACT $v i v$

$\begin{array}{ll}\text { I. INTRODUCTION } & 1\end{array}$

II. DETERMINANTS OF POTENTIAL OUTPUT GROWTH 2

III. METHODOLOGY 9

A. Assessment of Robust Determinants of Potential Growth 9

B. Assessing the Magnitude of Effects on Potential Output Growth 11

IV. RESULTS OF BAYESIAN MODEL AVERAGING

V. RESULTS OF PANEL DATA REGRESSION ANALYSES 15

A. Full Sample Results 16

B. Spillover Effects of the Growth of the People's Republic of China
and the United States

VI. THE IMPACT OF REFORMS ON POTENTIAL OUTPUT GROWTH IN ASIA 23

$\begin{array}{ll}\text { VII. CONCLUSION } & 25\end{array}$

$\begin{array}{lr}\text { APPENDIXES } & 27\end{array}$

$\begin{array}{ll}\text { REFERENCES } & 41\end{array}$ 


\section{TABLES AND FIGURES}

\section{TABLES}

1 Possible Determinants of Potential Growth 5

2 Fixed Effects Panel Regression Results-Full Sample

3 Fixed Effects Panel Regressions Results-Spillover Effects of the Growth of the People's Republic of China and the United States

4 Average Incremental Potential Output Growth

\section{FIGURES}

$1 \quad$ Posterior Inclusion Probabilities

2 Marginal Impact of Tertiary Level Gross Enrollment Ratio on Potential Output Growth

3 Marginal Impact of Trade Openness on Potential Output Growth

4 Marginal Impact of Proxy for Financial Integration on Potential Growth

20

5 Marginal Impact of Proxy for the Technology Gap with the United States on Potential Output Growth 


\begin{abstract}
Potential output growth generally decelerated after the global financial crisis during 2008-2009. This paper examines the possible determinants of potential output growth using Bayesian Model Averaging and assesses how the determinants can be used to increase the growth of potential output. It finds that the long-term growth of working-age population, the tertiary level gross enrollment ratio, the technology gap with the United States (US), labor market rigidity, trade openness, financial integration and the quality of institutions robustly affect potential output growth. Using Harrod's definition of potential output growth as the sum of the long-run growth rates of the labor force and labor productivity, we find that the trend growth rate of working-age population is a good proxy variable for long-run labor force growth. Under this definition, the other determinants affect potential output growth through their impact on the growth of labor productivity. The paper finds support for the hypotheses that tertiary enrollment and trade openness affects potential output growth nonlinearly. It also finds that trade openness and tertiary enrollment have nonlinear effects on potential output growth, and that the technology gap with the US and financial integration have statistically significant interaction effects on potential output growth. Results suggest that reforms aimed at reducing the technology gap with the US and increasing the extent of financial integration have lower impact on countries with high-quality institutions.
\end{abstract}

Keywords: determinants of growth, potential output growth, reforms

JEL codes: $\mathrm{O} 29, \mathrm{O} 41, \mathrm{O} 43, \mathrm{O} 47$ 


\section{INTRODUCTION}

The global financial crisis (GFC) during 2008-2009 generally led to lower average actual output growth during 2008-2014 for most countries. Although the GFC primarily affected advanced economies, contagion effects were also felt in upper-middle-income and some lower-middle-income economies. The economic downturn was not entirely cyclical either. Estimates of potential output growth during 2008-2014 are lower than the average during 2000-2007. Economic activity declined significantly during 2008-2009, and the sluggish pace of economic recovery in developed economies underpins the growing concern that a global low growth environment will persist in the medium to long run. This has implications for the growth trajectory of potential output.

Policy makers in most economies are concerned with accelerating economic growth in the aftermath of the GFC. This is especially so in developing and emerging economies where a substantial proportion of the population is still living in poverty, and lower growth paths in the future would be a significant obstacle to poverty alleviation. Can governments intervene and effectively steer growth toward a persistently higher growth path? The answer to this question depends on the effects of policies that tend to increase potential output growth, rather than in short-term stabilization policy instruments. This paper aims to establish statistically robust determinants of potential output growth and to evaluate whether they could be used to accelerate the growth of potential output.

The theoretical literature does not explicitly state what factors determine long-term output growth other than the basic variables in the Harrod-Domar and Solow-Swan models and their extensions. Beyond technology and innovation, capital accumulation (both physical and human), labor force growth, and initial resource endowments, several other factors could potentially affect output growth. Examples of growth determinants in the literature include market distortions, wealth concentration, geographic and climate factors, industry structures, the quality of governance, ethnicity of the population, the sociopolitical structure, openness to trade, and capital account liberalization. Indeed, the empirical literature on the determinants of economic growth points to large number of potentially relevant factors. This diversity and the lack of a clear-cut model selection method dictated by theory generate model uncertainty in relation to which factors are "true" determinants of output growth.

We focus on the determinants of potential output growth rather than add to the literature on empirical determinants of actual economic growth. To our knowledge, there is no existing literature on the determinants of potential output growth. We define potential output growth as the maximum growth rate of output that can be sustained without raising inflation. Compared to actual growth, the growth of potential output should be dictated by a smaller set of determinants since it is not affected by factors that drive business cycles. We could think of actual output growth as having two components: (i) a permanent or full potential output growth component; and (ii) a cyclical component driven by short-term factors and shocks. Our interest is only on the determinants of the first component.

The problem of model uncertainty remains even with a smaller set of possible determinants of potential output growth. Following a recent strand of empirical literature on the determinants of economic growth, we employ Bayesian Model Averaging (BMA) approach to find out which of the possible determinants robustly affect potential output growth. The ultimate goal of the paper is to assess the usefulness of the robust determinants of potential output growth. If potential growth has relatively high elasticities relative to some robust determinants that could be influenced by reforms or 
other forms of policy interventions, then these determinants could be used as policy levers to accelerate potential growth.

The rest of the paper is structured as follows. Section II presents a brief review of the literature on the determinants of output growth, provides a rationale for the development of our data set of possible determinants of potential output growth, and presents a brief descriptive analysis of the data set. Section III briefly outlines the methodology, while sections IV and V discuss the results of our econometric analyses. Section VI discusses the impact of policy reforms on potential output growth, and section VII concludes the paper.

\section{DETERMINANTS OF POTENTIAL OUTPUT GROWTH}

We use the hypotheses of theoretical economic growth models as our point of departure in selecting variables that could possibly determine potential output growth. We then briefly review the empirical literature on the determinants of actual output growth to expand our list of possible determinants of potential output growth.

In their seminal work on the theory of economic growth, Harrod (1939) and Domar (1946) stress that the growth of full employment output is determined by the sum of the growth of the labor force and change in the productivity of labor. ${ }^{1}$ Domar (1946) stresses that labor productivity is not exogenously determined. It is affected by the rate of capital accumulation, which is in turn governed by an exogenously determined savings rate. The rate of technical progress, while positively affecting labor productivity, is likewise assumed to be exogenous in the Harrod-Domar model of full employment output growth. The neoclassical model proposed by Solow (1956) and Swan (1956) similarly stresses the importance of capital accumulation, and maintains the assumption that the savings rate and technical progress are exogenous. ${ }^{2}$ Extensions of the neoclassical model include human capital accumulation as a factor that raises labor factor productivity, and adds innovation as a factor that drives technical progress. ${ }^{3}$

The assumption that the savings rate is exogenous is no longer invoked in most modern models of economic growth. Households are assumed to maximize a discounted utility function subject to an intertemporal budget constraint, and end up choosing an optimal consumption and savings path. Sala-i-Martin (1997) notes that, “... the optimal savings rate is a complicated function for which there are, in general, no closed form solutions". ${ }^{4}$ The theoretical growth models have also been extended to open economy settings which typically assume limited labor mobility and full trade and capital account openness. In theory, open economies obtain higher output growth potential through enhanced resource allocation, consumption smoothing, and risk sharing.

The most recent class of models of economic growth abandon the assumption of constant returns to scale invoked in the Harrod-Domar and neoclassical growth models and contends that

\footnotetext{
The notion of full employment output growth in the Harrod-Domar model is equivalent to our definition of potential output growth, which follows the concept introduced by Okun in 1962.

2 The differences in assumptions and results pertaining to the Harrod-Domar and Solow-Swan models will be not be discussed here. For our purposes, it suffices to note that the underlying determinants of full employment output growth are the same for both models.

3 See Nelson and Phelps (1966) and Becker, Murphy, and Tamura (1994).

4 See Sala-i-Martin (1997), p. 2.
} 
economic growth is driven from within the economic system. These models do not depend on exogenous influences such as technological progress and emphasize the endogeneity of output growth. Endogeneity stems from imperfect competition, externalities, and spillover effects from innovation. We note that the literature on endogenous growth does not basically alter the underlying factors that drive full employment growth in the Solow-Swan models. ${ }^{5}$

Easterly and Levine (2001) note that the literature on growth accounting reveals that it is not capital accumulation that is driving long-term economic growth, but changes in total factor productivity. Capital accumulation is still an important factor, but its importance varies across economies in relation to their state of economic development. They highlight the importance of national policies in shaping the long-term growth path of output.

To proceed with our analysis, we estimate potential output growth for the economies listed in Appendix 1 using aggregate supply models that relate the difference of economic growth from potential growth to the difference between actual and expected inflation. Econometric models that relate economic output growth, potential output growth, and inflation are estimated for each economy included our sample, and the estimates of potential output growth are obtained. The methodology is discussed in greater detail in Appendix 3.

We develop our data set of possible determinants of potential output growth by initially including the key variables in the Harrod-Domar model as well as the Solow-Swan growth model and its extensions. In particular, we include the trend growth rate of working-age population, the growth of the capital-labor ratio, the growth of human capital, a proxy for the technology gap with the US, and the research and development expenditures relative to gross domestic product (GDP). We also include the sectoral shares of employment as proxy variables for the current state of economic development. All other possible determinants are drawn from the empirical literature on the determinants of actual growth.

Sala-i-Martin (1997) examines 59 possible determinants of growth, which are grouped into 14 categories: (i) geographic location variables; (ii) political variables; (iii) religious affiliation variables; (iv) market distortions and market performance variables, including real exchange rate distortions; (v) investment variables; (vi) primary production sector variables; (vii) economic openness variables; (viii) the type of economic system; (ix) a colonization dummy variable; (x) education variables; (xi) ethnolinguistic variables; (xii) financial reform variables; (xiii) demographic structure; and (xiv) initial incomes and life expectancy in 1960. He finds 20 variables that are positively correlated with growth.

Sala-i-Martin, Doppelhofer, and Miller (2004) examine possible determinants of long-term economic growth and employ Bayesian Averaging of Classical Estimates (BACE) to determine statistically robust determinants. They test 67 possible determinants for robustness, the categories of which are broadly similar to those used by Sala-i-Martin (1997). They find 18 robust and 3 marginally robust determinants of long-term economic growth. ${ }^{6}$

5 Romer (1994) presents a brief overview of the underlying issues that are addressed by the endogenous growth literature.

6 Robustness here is defined as having posterior inclusion probabilities (PIPs) of 0.5 or greater. Marginally robust determinants are defined to have PIPs from 0.1 to 0.49. These criteria are discussed in greater detail in Section IIIA. 
Moral-Benito (2012) uses the Solow Growth Model as a baseline, and specifies initial income, the rates of physical and human capital accumulation, and population growth as determinants of output growth. He augments these with 30 additional determinants that he classifies under three broad categories: (i) macroeconomic and external environment variables including economic openness, (ii) institutions and governance, and (iii) geographic and fixed factors. He relies on panel data and uses Bayesian Model Averaging of Maximum Likelihood Estimates (BAMLE) and BMA to assess the robustness of the possible determinants of output growth. He finds nine robust determinants comprised of initial incomes, initial population, life expectancy, urban and total population growth, air distance, political rights, openness, and the price of investments.

Leon-Gonzales and Vinagayathasan (2013) examine potential determinants of growth in Asian economies. They assess 14 possible determinants of output growth for robustness and employ BMA on panel data for 27 developing Asian economies in 1980-2009. Their variables are comprised of initial income and population, population growth and population density, demographic variables, investment price and the investment rate relative to GDP, fiscal spending, education variables, inflation, trade openness and the terms of trade. Their findings suggest that the investment rate and trade openness are positively correlated with output growth. They find that government expenditures, on the other hand, are negatively correlated with the rate of growth of output in Asian economies.

Following Sala-i-Martin (1997); Sala-i-Martin, Doppelhofer, and Miller (2004); and MoralBenito (2012), we include several education-related variables, trade and capital account openness variables, financial reform and liberalization indexes, institutional quality variables, the share of industry and services in total employment, and the importance of raw and primary products in a country's export basket in our list of possible determinants of potential output growth. We exclude geographic location, proxy variables for spatial characteristics and other country-level fixed factors, the distribution of religious affiliation, distribution of ethnicity, and public health-related variables from the analyses. ${ }^{7}$ We put greater emphasis on institutional quality by adding seven institutional quality indicators; six of which are from the World Bank Worldwide Governance Indicators database and one from the World Bank Doing Business database.

We assert the importance of the quality of institutions as determinants of potential output growth based on the arguments presented in a report produced by the World Bank (2005) which emphasizes the relevance of governance and institutions for economic development. Rodrik (2006) argues that, in addition to problems in the conduct of economic policy reforms detailed in the World Bank Report, the lack of emphasis on institutional reforms failed to produce lasting gains from standard reform packages such as macro stabilization, trade and capital account openness, domestic liberalization and fiscal prudence. One of the lessons learned by the World Bank and the International Monetary Fund in their conduct of guiding policy reforms in the 1990s is that sound policies need to be complemented by sound institutions.

The importance of institutions for economic growth is widely documented. Acemoglu, Johnson, and Robinson (2001) find evidence that institutions brought by Europeans into their colonies in Asia and Africa explain present day income differences across former colonies. Acemoglu, Johnson, and Robinson (2005) develop a theory that relates the interdependence of economic and political institutions, and shows how these affect long-run economic performance. Easterly and Levine (2003)

7 As we will discuss later, fixed effects, panel regression is used in the paper. The effects of any significant fixed factors such as geographic characteristics are subsumed in the fixed effect component. 
find that geographic location and endowments affect economic development in conjunction with institutions. Babecky and Campos (2011) conduct a meta-analysis of 46 studies on the relationship between economic growth and reform, and find that the distribution of estimated effects of reform on growth is normally distributed. They also find that institutions and initial conditions are principal factors in increasing the probability of reporting significant and increasingly positive effects of reform on economic growth.

Table 1 shows the definitions and summary statistics of the 34 possible determinants of potential output growth that we consider in this paper. We classify the determinants into six categories: (i) variables in the Solow-Swan growth model and its extensions; (ii) a variable that acts as a proxy for the initial state of development, which will be used to test the convergence hypothesis; (iii) proxy variables for education; (iv) proxy variables for economic openness; (v) proxy variables for institutional quality; and (vi) proxy variables for economic structure. The table also presents the variables' unit of measure and their summary statistics.

\section{Table 1: Possible Determinants of Potential Growth}

\begin{tabular}{|c|c|c|c|c|c|c|}
\hline Variable Name & Variable Definition & Units & Mean & SD & Min & Max \\
\hline \multicolumn{7}{|c|}{ Solow-Swan growth variables } \\
\hline g-wap_tr & $\begin{array}{l}\text { Growth rate of working-age } \\
\text { population }\end{array}$ & $\%$ & 1.78 & 1.53 & -1.94 & 19.95 \\
\hline g-hc & $\begin{array}{l}\text { Growth rate of human } \\
\text { capital index }\end{array}$ & $\%$ & 0.85 & 0.69 & -2.24 & 4.59 \\
\hline di16merdt & R\&D expenditures & $\%$ of GDP & 0.98 & 0.92 & 0.00 & 4.86 \\
\hline g_ck_emp & $\begin{array}{l}\text { Growth of the capital-labor } \\
\text { ratio }\end{array}$ & $\%$ & 3.57 & 5.16 & -19.12 & 37.30 \\
\hline gap100 & $\begin{array}{l}\text { Technological gap with the } \\
\text { US }\end{array}$ & $\%$ & 54.12 & 37.28 & -336.00 & 97.00 \\
\hline \multicolumn{7}{|c|}{ Convergence variable } \\
\hline$g d p p c_{-} y 0$ & $\begin{array}{l}\text { GDP per capita at the start of } \\
\text { each decade }\end{array}$ & $\begin{array}{c}\text { in } 2005 \text { PPP US } \\
\text { dollars }\end{array}$ & $12,765.70$ & $14,166.94$ & 121.19 & $72,867.00$ \\
\hline \multicolumn{7}{|c|}{ Education system variables } \\
\hline estenrop & $\begin{array}{l}\text { Gross enrollment ratio, } \\
\text { Primary }\end{array}$ & $\begin{array}{l}\text { \% of population of } \\
\text { the age group that } \\
\text { officially } \\
\text { corresponds to } \\
\text { primary level }\end{array}$ & 102.82 & 11.74 & 37.95 & 161.81 \\
\hline eszenros & $\begin{array}{l}\text { Gross enrollment ratio, } \\
\text { Secondary }\end{array}$ & $\begin{array}{l}\text { \% of population of } \\
\text { the age group that } \\
\text { officially } \\
\text { corresponds to } \\
\text { secondary level }\end{array}$ & 80.10 & 26.19 & 4.50 & 170.95 \\
\hline es3enrot & $\begin{array}{l}\text { Gross enrollment ratio, } \\
\text { Tertiary }\end{array}$ & $\begin{array}{l}\text { \% of population of } \\
\text { the age group that } \\
\text { officially } \\
\text { corresponds to } \\
\text { tertiary level }\end{array}$ & 31.68 & 21.20 & 0.00 & 101.40 \\
\hline es10schom & $\begin{array}{l}\text { Mean years of schooling } \\
\text { completed in population } \\
\text { over } 14\end{array}$ & Years & 7.94 & 2.34 & 1.80 & 13.02 \\
\hline es12educe & $\begin{array}{l}\text { Current and capital public } \\
\text { expenditure on education }\end{array}$ & $\%$ of GDP & 4.43 & 1.64 & 0.89 & 9.47 \\
\hline es14teacr_plus & Pupil-teacher ratio, Primary & $\%$ & 22.47 & 9.00 & 6.78 & 63.00 \\
\hline
\end{tabular}


Table 1 continued

\begin{tabular}{|c|c|c|c|c|c|c|}
\hline Variable Name & Variable Definition & Units & Mean & SD & Min & Max \\
\hline \multicolumn{7}{|c|}{ Economic openness variables } \\
\hline overall_glob & Overall globalization index & Index $(0-100)$ & 57.57 & 18.90 & 11.77 & 92.37 \\
\hline ka_open & Capital account openness & Index $(0-1)$ & 0.55 & 0.37 & 0.00 & 1.00 \\
\hline fin_ref & Financial reform index & Index (0-1) & 0.53 & 0.31 & 0.00 & 1.00 \\
\hline Trade & $\begin{array}{l}\text { Measure of trade openness - } \\
\text { sum of export and imports } \\
\text { divided by GDP }\end{array}$ & $\%$ of GDP & 71.73 & 60.48 & 4.98 & 455.28 \\
\hline pe_index & $\begin{array}{l}\text { Portfolio equity integration } \\
\text { index }\end{array}$ & $\%$ of GDP & 63.27 & 487.55 & 0.00 & $8,238.74$ \\
\hline fdi_index & FDI integration index & $\%$ of GDP & 77.18 & 466.15 & -14.62 & $9,079.26$ \\
\hline integr_index & Integration index & $\%$ of GDP & 336.95 & $1,632.16$ & 9.75 & $24,074.93$ \\
\hline \multicolumn{7}{|c|}{ Quality of institution variables } \\
\hline voa & $\begin{array}{l}\text { Voice and accountability } \\
\text { index }\end{array}$ & $\begin{array}{c}\text { Standardized z- } \\
\text { scores }(-2.5-2.5)\end{array}$ & 0.40 & 1.02 & -2.21 & 1.83 \\
\hline polstab & Political stability index & $\begin{array}{c}\text { Standardized z- } \\
\text { scores }(-2.5-2.5)\end{array}$ & 0.17 & 0.96 & -2.81 & 1.67 \\
\hline goveff & Government efficiency index & $\begin{array}{c}\text { Standardized z- } \\
\text { scores }(-2.5-2.5)\end{array}$ & 0.63 & 0.99 & -1.68 & 2.43 \\
\hline rega & Regulatory quality index & $\begin{array}{c}\text { Standardized z- } \\
\text { scores }(-2.5-2.5)\end{array}$ & 0.58 & 0.96 & -2.18 & 2.25 \\
\hline rol & Rule of law index & $\begin{array}{c}\text { Standardized z- } \\
\text { scores }(-2.5-2.5) \\
\end{array}$ & 0.50 & 1.03 & -1.69 & 2.00 \\
\hline cocorr & Control of corruption index & $\begin{array}{c}\text { Standardized z- } \\
\text { scores }(-2.5-2.5)\end{array}$ & 0.54 & 1.14 & -1.50 & 2.59 \\
\hline pflcorri & Corruption perception index & Index $(0-10)$ & 5.19 & 2.42 & 0.40 & 10.00 \\
\hline lamrig & Labor market rigidity index & Index $(0-3.5)$ & 1.53 & 0.64 & 0.00 & 3.50 \\
\hline $\operatorname{lm} r$ & $\begin{array}{l}\text { Index of labor market } \\
\text { regulations }\end{array}$ & Index $(0-10)$ & 5.77 & 1.52 & 2.30 & 9.50 \\
\hline \multicolumn{7}{|c|}{ Economic structure variables } \\
\hline$r m \_e x$ & $\begin{array}{l}\text { Share of raw materials } \\
\text { exports in total exports }\end{array}$ & $\%$ of total exports & & & & \\
\hline fm_ex & $\begin{array}{l}\text { Share of mining and fuels } \\
\text { exports in total exports }\end{array}$ & $\%$ of total exports & & & & \\
\hline$r m f m \_e x$ & $\begin{array}{l}\text { Share of raw materials, } \\
\text { mining and fuels exports in } \\
\text { total exports }\end{array}$ & $\%$ of total exports & 24.71 & 25.11 & 0.38 & 98.57 \\
\hline ind_emp_sh & $\begin{array}{l}\text { Share in total employment, } \\
\text { Industry }\end{array}$ & $\begin{array}{c}\% \text { of total } \\
\text { employment }\end{array}$ & 24.95 & 7.09 & 5.72 & 59.60 \\
\hline ser_emp_sh & $\begin{array}{l}\text { Share in total employment, } \\
\text { Services }\end{array}$ & $\begin{array}{c}\% \text { of total } \\
\text { employment }\end{array}$ & 56.48 & 15.74 & 13.10 & 88.00 \\
\hline agr_emp_sh & $\begin{array}{l}\text { Share in total employment, } \\
\text { Agriculture }\end{array}$ & $\begin{array}{c}\% \text { of total } \\
\text { employment }\end{array}$ & 18.70 & 18.39 & 0.10 & 79.09 \\
\hline
\end{tabular}

$\mathrm{FDI}=$ foreign direct investment, GDP = gross domestic product, $\mathrm{PPP}=$ purchasing power parity, $\mathrm{R} \& \mathrm{D}$ = research and development, US = United States.

Source: Authors' calculations. 
The unbalanced panel data set we use to investigate potential output growth and its determinants covers 70 economies, with annual data over the period 1970-2014. ${ }^{8}$ The descriptive statistics of the possible determinants of potential output growth and their bivariate correlations are briefly discussed below.

We have five Solow-Swan growth model variables in our list of potential output growth determinants: (i) the trend growth rate of working-age population, (ii) the growth rate of the index of human capital, (iii) the intensity of research and development expenditures measured as the ratio of research and development (R\&D) expenditures to GDP, (iv) the growth rate of the capital-labor ratio, and $(v)$ the technology gap with the US. The mean growth rate and standard deviation of working-age population over the period 1970-2014 are 1.78\% and 1.53\%, respectively for our entire set of countries. The mean growth rate of the human capital index has a lower mean of $0.85 \%$, while the R\&D expenditures ratio has a mean of $0.98 \%$. Among the variables that are typically found in Solow-Swan growth models, the technological gap with the US has the highest mean at 54\% and largest standard deviation at $37.28 \%$.

We include the initial GDP per capita as a proxy variable for the initial stage of economic development. ${ }^{9}$ Under the convergence hypothesis, advanced economies will typically have higher per capita incomes and slower actual and potential output growth.

Our list of potential output growth determinants also contains six proxy variables for human capital formation from the Cross-Country Analyses of National Systems, Growth and Development (CANA) Database..$^{10}$ These are the gross enrollment ratios in the primary, secondary, and tertiary levels, the mean number of years of completed schooling for the segment of the population that is more than 14 years old, public expenditures on education, and the primary pupil-teacher ratio. The average gross enrollment ratios in our entire data set are $103 \%$ at the primary level, $80 \%$ at the secondary level, and 32\% at the tertiary level." On average, an individual over 14 years old has 8 years of schooling, and primary schools have approximately 22.5 enrolled pupils for every teacher. Summary statistics by country subgroups, shown in the Appendix 6, indicate that the mean values of gross enrollment ratios at the secondary and tertiary levels for high-income economies are higher compared to middle- and low-income economies. High-income economies also have a lower pupil to teacher ratio at approximately 17 enrollees for every teacher.

The economic openness variables include different measures for degree of globalization, integration, and financial reform. The mean index of globalization of all economies in our sample is 57.6 with a standard deviation of 18.9. The least globalized economy has an index value of 11.8, while the most globalized has an index value of 92.4. This implies that the distribution of globalization is skewed to the right since the mean is higher than the median globalization index for all economies. This feature of the distribution also characterizes the capital account openness and financial reform

8 The list of countries is provided in Appendix 1 and the detailed definitions and sources of data used in this paper are in Appendix 2.

9 We use the initial GDP per capita at the start of each decade in our sample so as to introduce variations in the data series. Since we are using panel data in our analyses, not doing so leads to collinearity and econometric estimation issues since the impact of this variable will be indistinguishable from the fixed effects component.

10 See Castellacci and Natera (2011) for the CANA Database documentation.

1 The enrollment ratios at the primary, secondary, and tertiary levels are computed as the number of enrolled individuals divided by the size of the segment of population whose age group corresponds to the officially defined level of schooling for that age group. 
indexes. In addition, the economies in our sample show a relatively high degree of trade openness and financial integration, although the measures exhibit equally high degrees of variability. The summary statistics by country subgroups, shown in Appendix 6, indicate that high-income economies have higher scores on the various measures of economic openness.

Six of the nine indicators of institutional quality in our data set are from the World Bank's World Governance Indicators (WGIs) database. The WGIs are estimated annually using data from multiple sources and an unobserved component model. ${ }^{12}$ They are expressed as standard normal scores with a range of -2.5 to 2.5 . Among the institutional quality variables sourced from World Bank's WGI, the index for political stability has the lowest mean at 0.17 , while the index for government efficiency has the highest at 0.63. Our 7th indicator of institutional quality, the index of perception of corruption, is sourced from the World Bank's Doing Business database and has a range of 0-10. Summary statistics by country subgroups, shown in Appendix 6, indicate that high-income economies have high mean scores on the various measures of institutional quality. In contrast, the mean scores of all institutional quality indicators of middle-income economies are quite low, which partly explains the relatively low mean scores of the full sample.

Our eighth and ninth indicators of institutional quality are the two indexes of labor market rigidity; (i) the index of labor market regulations from the EFW annual reports and (ii) the labor market rigidity index sourced from the World Bank's Doing Business Database and Campos and Nugent (2012). Both indexes are de jure measures that are meant to quantify the extent of barriers to labor market adjustment due to regulations imposed by the government. Wage regulations, worker protection measures, protective measures against unjust termination, and the availability of alternative labor contracts are included in the computation of the indexes. The labor market rigidity index has a range of 0-3.5. Our sample of countries has a mean labor market rigidity index of 1.53 and a standard deviation of 0.64. High-income economies in our sample have a slightly lower mean labor market rigidity index of 1.43 compared to the mean value of 1.68 for middle-income economies. The standard deviations of the labor market index in high- and medium-income economies are 0.73 and 0.46 , respectively.

The variables characterizing economic structure in our data set include the share of raw materials, and fuel and mining exports in total exports, and the sectoral employment shares. The mean share of raw materials, fuel and mining products in total exports of all economies in our sample is $25 \%$. The services and agriculture sectors in the entire sample have mean employment shares of $56 \%$ and $19 \%$, respectively. We note that industrial sector employment has the lowest dispersion among economies in our sample, while that of the agriculture sector has the highest variability. Summary statistics by country subgroups, shown in Appendix 6, indicate a similar pattern of distribution for highincome economies.

Appendix 7 shows the bivariate correlation matrix for our entire sample. It indicates that the institutional quality variables from the World Bank's WGI are highly correlated with each other and with various education variables like secondary and tertiary gross enrollment. They are also highly correlated with the indicators of economic openness such as the capital account openness index, the financial reform and liberalization indexes, and with the research and development expenditures, and the proxy variable of the technological gap. Not surprisingly, initial GDP per capita is highly and positively correlated with enrollment levels, economic openness, and the quality of institutions.

12 See Kaufmann, Kraay, and Mastruzzi (2010). 


\section{METHODOLOGY}

We examine the possible determinants of potential growth in our data set in two stages. We first assess the robustness of possible determinants using a version of the BMA proposed by Magnus et al. (2010). Robust determinants that are identified using this BMA technique are then used as regressors in a fixed effects panel data regression to gauge their effects on potential output growth. We briefly discuss each stage below.

\section{A. Assessment of Robust Determinants of Potential Growth}

We employ BMA to address uncertainty in the true determinants of potential output growth. The basic paradigm for BMA was introduced by Leamer in 1978, and is widely used in the literature on determinants of economic growth. ${ }^{13}$ Hoeting et al. (1999) describes BMA as a "coherent mechanism for accounting for model uncertainty," specifically with regard to model selection. ${ }^{14}$

Following Leon-Gonzales and Vinagayathasan (2013), we employ Bayesian Panel Data Model Averaging to extract the robust determinants of potential output growth from our data set of 34 possible determinants. Our unbalanced panel data set covers a cross-section of 70 economies from the Organization of Economic Cooperation and Development (OECD), Asia and the Pacific, Latin America, the Middle East and Africa, and a time series that spans the period 1970-2014 for most variables.

Our basic estimation equation is as follows:

$$
g_{k t}=\mu_{k}+\gamma^{T} X_{k t}+\beta^{T} W_{k t}+\epsilon_{k t}
$$

where

$\begin{array}{ll}g_{k t} & \text { is potential output growth of country k at time t } \\ \mu_{k} & \text { is a fixed country-effect for country k } \\ \gamma^{T} & \text { is a } 1 \times N_{1} \text { vector of parameters } \\ \beta^{T} & \text { is a } 1 \times N_{2} \text { vector of parameters } \\ X_{k t} & \text { is an } N_{1} \times 1 \text { vector of endogenous determinants of for country k's } \\ W_{k t} & \text { potential growth } \\ & \text { is an } N_{2} \times 1 \text { vector of exogenous determinants of country k's potential } \\ \epsilon_{k t} \sim \text { i.i.d. }\left(0, \sigma_{\varepsilon}^{2}\right) & \text { growth }\end{array}$

A BMA estimation procedure for Equation (1) involves estimating classical panel data regression models of all combinations of possible determinants of potential output growth, where each combination of regressors are nonempty subsets of the set defined by $\left\{X_{k t} \cup W_{k t}\right\}$. Following Magnus et al. (2010), we allow one or more of the possible determinants in $X_{k t}$ and $W_{k t}$ to be specified as fixed or focus regressors; such that they always appear in all model specifications in the model space. Specifically, let $n_{1}$ of the $N_{1}$ endogenous variables and $n_{2}$ of the $N_{2}$ exogenous variables be fixed or focus variables. The BMA estimation procedure is used on the following specification where the regressors are partitioned into fixed and auxiliary regressors:

13 See, for example, Sala-i-Martin, Doppelhofer, and Miller (2004); Moral-Benito (2012); Leon-Gonzales and Vinagayathasan (2013).

14 Hoeting et al. (1999), p. 1. 


$$
g_{k t}=\mu_{k}+\left[\begin{array}{ll}
\gamma_{F}^{T} & \gamma_{A}^{T}
\end{array}\right]\left[\begin{array}{l}
X_{k t}^{F} \\
X_{k t}^{A}
\end{array}\right]+\left[\begin{array}{ll}
\beta_{F}^{T} & \beta_{A}^{T}
\end{array}\right]\left[\begin{array}{l}
W_{k t}^{F} \\
W_{k t}^{A}
\end{array}\right]+\epsilon_{k t}
$$

where

$$
\begin{aligned}
& g_{k t} \\
& \mu_{k} \\
& \gamma_{F}^{T} \text { and } \beta_{F}^{T} \\
& \gamma_{A}^{T} \text { and } \beta_{A}^{T} \\
& X_{k t}^{F} \text { and } W_{k t}^{F} \\
& X_{k t}^{A} \text { and } W_{k t}^{A} \\
& \epsilon_{k t} \sim i . i . d .\left(0, \sigma_{\varepsilon}^{2}\right)
\end{aligned}
$$

is potential output growth of country k at time $t$ is a fixed country-specific effect for country $k$ are $1 \times n_{1}$ and $1 \times n_{2}$ vectors of coefficients of focus variables are $1 \times\left(N_{1}-n_{1}\right) \& 1 \times\left(N_{2}-n_{2}\right)$ vectors of coefficients of aux. variables are $n_{1} \times 1$ and $n_{2} \times 1$ vectors of focus variables are $\left(N_{1}-n_{1}\right) \times 1$ and $\left(N_{2}-n_{2}\right) \times 1$ vectors of auxiliary variables

The number of auxiliary regressors determines the size of the model space..$^{15}$ In particular, given $\mathrm{N}_{1}+\mathrm{N}_{2}=\mathrm{N}$ regressors of which $n_{1}+n_{2}=n$ are focus variables, the model space or number of nonnull subsets of auxiliary variables is $2^{(\mathrm{N}-n)}$. $^{16}$

We consider all possible determinants in our data set as endogenously determined, except for the indices of institutional quality. We specify the trend growth rate of working-age population as a focus variable in our BMA analyses. Following Harrod (1939) and Domar (1946), we define potential output growth as the sum of the growth rates of the labor force and labor productivity. Under this definition, our BMA specification with the trend growth rate in working-age population as a focus variable reflects the argument that the auxiliary determinants affect labor productivity growth.

The BMA procedure in Stata is not designed to handle the fixed effects component in panel regression models. Hence, we use the forward orthogonal deviation (FOD) transformation on all variables to cancel out country-specific fixed effects in our panel data BMA model. ${ }^{17}$ We also use the first-order lags of endogenous regressors as instruments so as to address potential problems that could arise from endogeneity. The FOD transformation and the use of instruments ensure that parameter estimates are consistent. BMA posterior mean estimates of model parameters are weighted averages of classical coefficient estimates. The weights used are the normalized posterior probabilities of coefficient estimates with the normalization done throughout the model space. The normalized posterior probability for parameter $\gamma_{j}$ or $\beta_{j}$ associated with an auxiliary variable $X_{j}$ or $W_{j}$ is defined by:

$$
\operatorname{Pr}\left(H_{j} \mid Y\right)=\frac{f\left(Y \mid H_{j}\right) \operatorname{Pr}\left(H_{j}\right)}{\sum_{j=1}^{N-n} f\left(Y \mid H_{j}\right) \operatorname{Pr}\left(H_{j}\right)}
$$

where $Y$ denotes the observed data, $H_{j}$ is the set of all specifications where the parameter $\gamma_{j}$ or $\beta_{j}$ in Equation (2) appears, $f\left(Y \mid H_{j}\right)$ is the marginal likelihood of $Y$ conditional on having parameter $\gamma_{j}$ or $\beta_{j}$ in the true model, and $\operatorname{Pr}\left(H_{j}\right)$ is the prior probability that auxiliary variable $X_{j}$ or $W_{j}$ is a true determinant of $Y$.

15 Auxiliary regressors are right-hand side variables that are not fixed and may not appear in all possible combinations of regressors (i.e., they are not focus variables).

16 The size of the model space is not trivial for relatively large values of $N-n$. Since there are 33 potential determinants in our data set, a specification composed solely of auxiliary regressors that uses the whole data set has a model space of $2^{33}=$ 8.59 billion.

17 Conducting FOD transformations on model variables is a superior alternative to getting first differences, since the latter introduces serial correlation in the error terms. 
Our main interest in using BMA is to obtain the respective posterior inclusion probability (PIP) of each possible determinant of potential output growth. The PIPs measure the likelihood that a particular variable is included in the "true" model of potential output growth. We follow Barbieri and Berger (2004) and classify the variables with PIPs greater than or equal to 0.5 as robust determinants of growth. Regressors with PIPs between 0.25 and 0.5 are considered marginally robust.

Despite being a useful tool for establishing a set of "robust" regressors given a large number of possible explanatory variables, the BMA methodology has some drawbacks. Ciccone and Jarocinski (2010), for example, show that the results of BMA could be highly sensitive to measurement errors. Ghosh and Ghattas (2015) show that high collinearity in three or more covariates tend to push the posterior inclusion probabilities downward to the extent that all collinear variables may be falsely excluded. In particular, they note that strong collinearity leads to a multimodal posterior distribution such that if there are three or more highly collinear variables, the median probability model could potentially discard all of them. They stress that the correlation matrix of regressors should be routinely examined, and that there is a need to calculate joint inclusion probabilities for correlated covariates. Doppelhofer and Weeks (2007) note that BMA's "emphasis on marginal measures of variable importance make it difficult (if not impossible) to detect dependence among explanatory variables." They stress that the extent of interdependence between explanatory variables will affect the posterior probability of any given model as well as the form of the posterior probability distribution of variables over the model space.

Since some of the variables in our data set have very high correlations, we eliminate some redundant indicators from the analysis. We then implement successive BMA estimation procedures and progressively reduce the model space by removing variables that are neither robust nor marginally robust. We also examine the impact of removing some highly correlated covariates from the data set. Our BMA specification has only one focus variable (i.e., the trend growth rate of working-age population) that is selected on the basis of the Harrod-Domar definition that full employment growth is the sum of the growth of the labor force and changes in the productivity of labor. ${ }^{18}$ With this definition, we implicitly assume that the auxiliary variables in our analysis affect labor force productivity.

The output from the BMA analyses provide a subset of robust determinants of potential output growth. These robust determinants are subsequently used as explanatory variables in several alternative specifications of fixed effects dynamic panel regression models. The results of which allow us to gauge the impact of the robust regressors on potential output growth.

\section{B. Assessing the Magnitude of Effects on Potential Output Growth}

We estimate Equation (1) using a fixed effects dynamic panel estimation procedure to assess the relative importance of the robust determinants of potential growth. We rely on Driscoll and Kraay (1998) standard errors, which are robust to heteroscedasticity, as well as very general forms of temporal dependence and/or cross-sectional dependence (e.g., due to spatial correlation or time effects). We adopt an estimation procedure that produces standard errors which are robust to the presence of autocorrelation and heteroscedasticity, and continue to use the first-order lags of endogenous regressors as instruments. We separately test for the significance of interaction effects

18 See Domar (1946), p. 138. 
between institutional quality variables and financial integration in line with the literature on the nonlinearity of effects of financial openness on economic growth. In a similar fashion, we also examine whether there is a statistically significant interaction effect between the technology gap with the US and institutional quality. Lastly, we conduct panel regression analyses on subsamples of economies using the same model specification to see if the determinants of potential output growth vary in highand middle-income economies.

\section{RESULTS OF BAYESIAN MODEL AVERAGING}

The posterior inclusion probabilities from the BMA estimation procedure and the complete set of possible growth determinants are shown in Figure 1. Recall that we specify the trend growth of working-age population as the only focus variable in our BMA analyses on the basis of the HarrodDomar definition that full employment output growth is equal to the sum of the growth rates of the labor force and labor productivity.

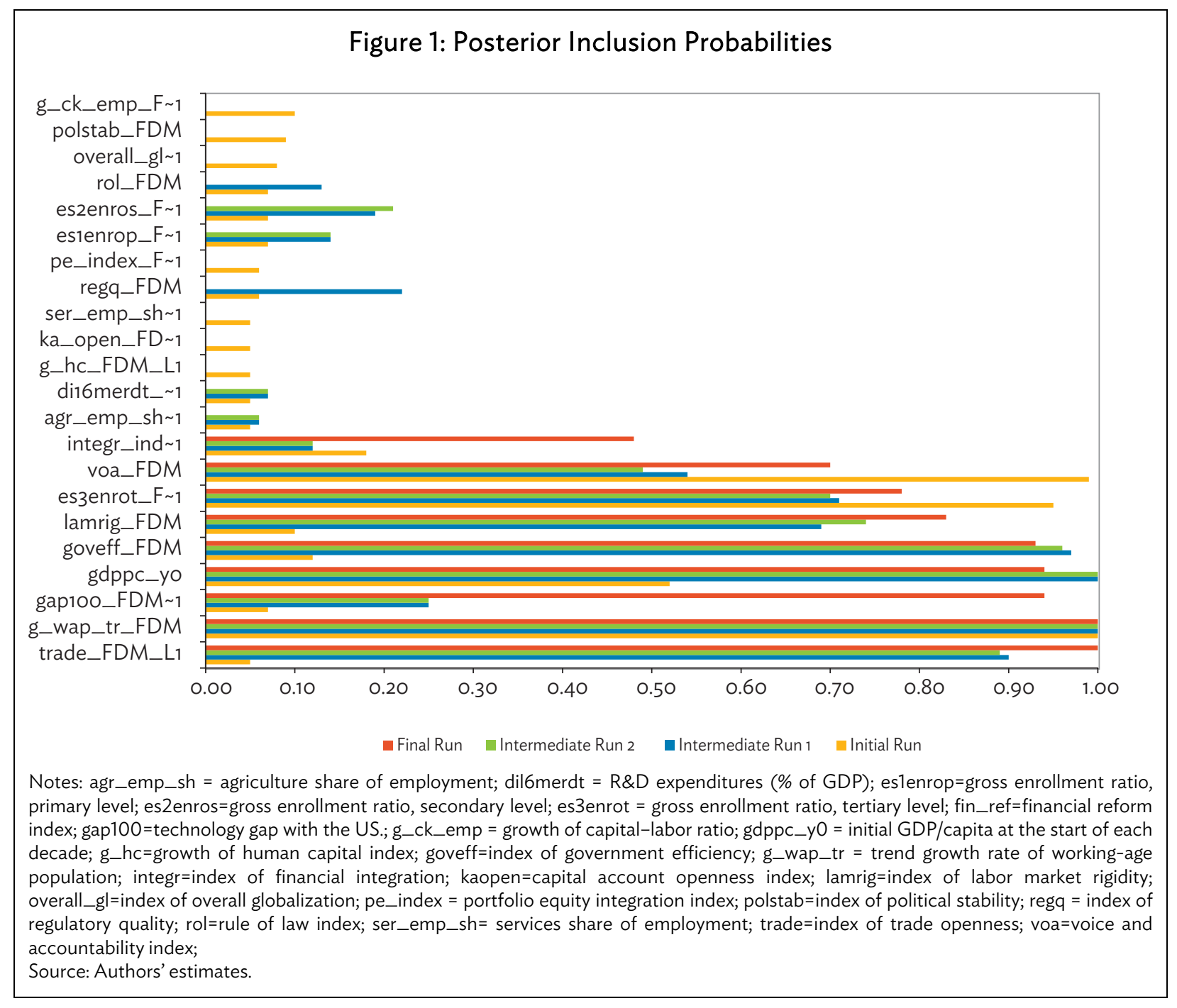


From the 33 remaining potential determinants of potential output growth, we reduce the list of possible determinants by 11 and select only 22 variables for inclusion into the BMA estimation. The reduction in the number of auxiliary regressors in our BMA analyses is motivated by the high correlations between several possible determinants of potential output growth in our data set. We do this in response to the findings of Doppelhofer and Weeks (2007) and Ghosh and Ghattas (2015). By limiting the number of auxiliary variables to 22 , we also reduce the model space. ${ }^{19}$

The focus variable is included in all specifications in the model space, and therefore has a PIP equal to 1. Of the 22 auxiliary variables in our BMA specification, we select four that are identified in the theoretical models of potential output growth (i.e., the trend growth rate of working-age population, the growth of the capital-labor ratio, the technology gap with the US, and growth of the human capital index); the initial GDP per capita to include a variable for testing the convergence hypothesis; three education variables; six variables reflecting trade, financial reform, and capital account openness; two proxy variables for the stage of economic development; and six institutional quality indicators.

We include all Solow-Swan model variables in our data set in the BMA analyses. We exclude some auxiliary variables from the analysis due to their high correlations with other variables within their categories (e.g., education variables are highly correlated with each other), and in some cases, with variables in other categories (e.g., openness variables are highly correlated with institutional quality variables).

We sequentially implemented four BMA analyses, beginning with our selected auxiliary variables and progressively removing nonrobust determinants at each stage. The results of the four BMA runs are summarized in Appendix 4. De Luca and Magnus (2011) note that for determinants to be considered robust, the absolute value of their t-ratios must be greater than or equal to 1, the PIPs must be greater than or equal to 0.5 , or zero is not within the 1-standard error band of the coefficient estimate. The statistics necessary to assess robustness in the four BMA runs are all shown in Appendix 4.

The posterior inclusion probabilities from our BMA analyses are shown in Figure 1. We obtain only three robust auxiliary variables from our initial BMA estimation procedure: (i) the gross enrollment ratio at the tertiary level, (ii) the initial GDP per capita, and (iii) the index of voice and accountability. Since we suspect that the BMA results are heavily influenced by the high degree of multicollinearity among our potential determinants of potential output growth, we drop some of the nonrobust and highly correlated regressors from our BMA model space and repeat the BMA estimation procedure to check for changes in robustness of remaining regressors. In particular, we delete (i) the growth of the capital-labor ratio, (ii) the growth rate of the human capital index, (iii) the capital account openness index, (iv) the overall globalization index, (v) the portfolio equity integration index, (vi) the index of political stability, and (vii) share of the agriculture sector in total employment. We delete the capital account openness index, the overall globalization index, and the portfolio equity integration index since they are highly correlated with trade openness and the index of financial integration. We also delete the share of agriculture sector employment since it is highly correlated with the services sector share of employment. We likewise drop the index for political stability from

19 As noted earlier, the size of the model space with 33 possible determinants in the data set is not trivial. By specifying one as a focus variable and removing 11 redundant variables from the data set, we have reduced the model space further to $2^{22}$ $=4.19$ million. 
succeeding BMA analyses since it has a very high correlation with the other institutional quality indicators. We also remove the growth rate of human capital and capital-labor ratio from the list of regressors due to their extremely low PIPs in the initial BMA analysis.

After removing the seven nonrobust regressors in our initial BMA analysis, the results of the first intermediate BMA analysis show that the index of trade openness, the index of government effectiveness, and the labor market rigidity index have become robust determinants of potential output growth. The statistically robust determinants in our initial run continue to show PIPs greater than 0.50 .

For our second intermediate BMA exercise, we exclude the indexes of the rule of law and regulatory quality from the model space since they remain nonrobust in the first intermediate BMA analysis. We note that they also have high correlations with the remaining auxiliary regressors. The results of our second intermediate BMA analysis, however, do not alter the list of robust variables produced in the first intermediate BMA estimation procedure, except for index of voice and accountability whose PIP went down from 0.54 to 0.49 .

In our final BMA analysis, we omit the share of agricultural employment in total employment, R\&D expenditures, the primary and secondary level gross enrollment ratios, and the financial reform index from the model space and reestimate the specification to check if all variables in the right-hand side will exhibit robustness. ${ }^{20}$ As shown in Figure 1, all remaining auxiliary variables continue to have PIPs greater than 0.50 , except for the index of financial integration which has a PIP of 0.48 . Note also that the technology gap with the US exhibits a substantial increase in its PIP after R\&D expenditures as a percentage of GDP is removed from the model space. ${ }^{21}$

To summarize, our BMA analyses reveal the following robust and marginally robust auxiliary determinants of potential output growth:

(i) initial GDP per capita,

(ii) tertiary level gross enrollment ratio,

(iii) indicator of financial integration,

(iv) indicator of trade openness,

(v) technology gap with the US,

(vi) index of government efficiency,

(vii) labor market rigidity index, and

(viii) index of voice and accountability.

${ }^{20}$ We delete the share of agricultural employment because it is highly correlated with the initial GDP per capita. We similarly delete the primary and secondary level gross enrollment ratios because of their high correlation with the tertiary level enrollment ratio. The deletion of R\&D expenditures and the financial reform index is likewise motivated by the high correlations with the technology gap with the US and the financial integration index, respectively.

${ }^{21}$ Our BMA analysis on the determinants of potential output growth, underlines some of the practical problems of the BMA approach which were pointed out earlier. In particular, the high correlation between and across institutional quality variables and other variables required the removal of some possible determinants of potential output growth from the model space. This resulted in some of the remaining variables gaining in robustness when some highly correlated regressors were excluded from the model space. 
We obtain seven robust auxiliary determinants of potential output growth from our series of BMA analyses out of 21 possible auxiliary determinants. ${ }^{22}$ The robust auxiliary determinants of potential output growth, together with the focus regressor, are consistent with the theoretical and empirical literature on the determinants of output growth, and supports the notion of growth convergence. Specifically, the initial GDP per capita as a proxy variable for the initial state of development and captures the possibility of growth convergence as incomes rise, while the trend growth rate of working-age population as a proxy variable for the growth of the labor force in Harrod's definition of potential output growth. The tertiary level gross enrollment ratio and the technology gap with the US as proxy variables for human capital accumulation and technological progress, respectively, are deemed to affect labor productivity growth, and are therefore consistent with the theories of full employment output or potential output growth. The trade openness and financial integration indexes are proxy variables for economic openness, and should, in theory, positively affect potential output growth through enhanced factor mobility, technology transfer and diffusion, and reduced price distortions. The labor market rigidity index, the index of government efficiency and the voice and accountability index are indicators of institutional quality which, in line with the recent literature on the role of institutions in the growth process, are likely to influence the growth trajectory of potential output.

\section{RESULTS OF PANEL DATA REGRESSION ANALYSES}

Given the results of our BMA analyses and keeping in mind the possibility of endogeneity problems in our regressors, the baseline model is explicitly written as:

$$
\begin{aligned}
& g_{k t}= \\
& \mu_{k}+\beta_{1} g d p p c_{-} y o_{k t}+\beta_{2} g_{-} \text {wap_tr }_{k t}+\beta_{3} \text { lamrig }_{k t}+\beta_{4} \text { voa }_{k t}+\beta_{5} \text { goveff }_{k t}+\gamma_{1} \text { trade }_{k, t-1}+ \\
& \gamma_{2} \text { es3enrot }_{k, t-1}+\gamma_{3} \text { gap }_{k, t-1}+\gamma_{4} \text { integr }_{\text {index }_{k, t-1}}+\epsilon_{k t}
\end{aligned}
$$

The variable names are defined in Table 1. Contrary to expectations, estimation of Equation 4 produces negative coefficients for the financial integration index and the level of tertiary education. ${ }^{23}$ We explore the possibility that this is due to the presence of nonlinearities, by augmenting the baseline model with the squared terms of the tertiary level gross enrollment ratio and the trade openness index. In addition, we also include a dummy variable to capture the effects of the GFC during 2008-2009 on potential output growth. The resulting model is thus specified as follows:

$$
\begin{aligned}
& g_{k t}=\mu_{k}+\beta_{1} g d p p c_{-} y o_{k t}+\beta_{2 \_} \text {wap_tr }_{k t}+\beta_{3} \text { lamrig }_{k t}+\beta_{4} \text { voa }_{k t}+\beta_{5} \text { goveff }_{k t}+
\end{aligned}
$$

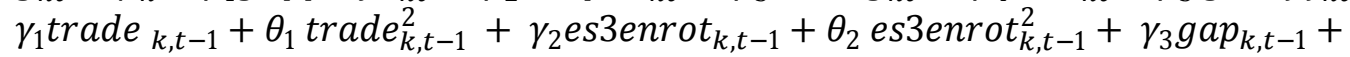

$$
\begin{aligned}
& \gamma_{4} \text { integr }_{\text {index }_{k, t-1}}+\gamma_{5} G F C_{t}+\epsilon_{k t}
\end{aligned}
$$

where GFC is a dummy variable that has a value of 1 if $t>2007$ and 0 otherwise.

In addition, we test for the statistical significance of the following interaction terms: (i) the interaction between the technology gap with the US and two institutional quality proxy variables (i.e., the index of voice and accountability and the index of political stability); and (ii) the interaction

\footnotetext{
22 Recall that we specified the trend growth rate of working-age population as a focus variable such that it always has a PIP of 1.

23 The estimation results for the baseline model are presented in Appendix 5.
} 
between the index of financial market integration and the indexes of regulatory quality and rule of law. We add the interaction terms to Equation (5) so the model becomes:

$g_{k t}=\mu_{k}+\beta_{1} g d p p c_{-} y o_{k t}+\beta_{2} g_{-} w_{\text {wap }} t r_{k t}+\beta_{3}$ lamrig $_{k t}+\beta_{4}$ voa $_{k t}+\beta_{5}$ goveff $_{k t}+$ $\gamma_{1}$ trade $_{k, t-1}+\theta_{1}$ trade $_{k, t-1}^{2}+\gamma_{2}$ es3enrot $_{k, t-1}+\theta_{2}$ es3enrot $_{k, t-1}^{2}+\gamma_{3}$ gap $_{k, t-1}+\alpha_{1}\left[\right.$ gap $_{k, t-1} \times$ inst $\left._{k, t-1}\right]+\gamma_{4}$ integr_index $x_{k, t-1}+\alpha_{2}\left[\right.$ integr_index $_{k, t-1} \times$ inst $\left._{k, t-1}\right]+\gamma_{5} G F C_{t}+\epsilon_{k t}$

where the variables inst 1 is either polstab or voa while inst 2 is either regq or rol.

We estimate four alternative specifications of Equation (6) using the full sample and subgroups of the economies in our data set to evaluate whether the effects of the robust determinants vary at different levels of income and stage of economic development.

\section{A. Full Sample Results}

The panel regression results for Equation (6) using the full sample are summarized in Table 2. Column 1 shows estimates for the specification in which the interaction term between the technology gap with the US and political stability index, as well as the interaction term between financial integration and proxy variable for regulatory quality are added to Equation (5). Column 2 shows the results for the version of the model in Equation (6) with the interaction terms between the technology gap with the US and the voice and accountability index, and between financial integration and regulatory quality index. Columns 3 and 4 show the results for specifications of Equation (6) which include the interaction terms between the indexes of financial integration and the rule of law, in addition to the interaction terms between the technology gap and index of political stability or the index of voice and accountability.

Table 2: Fixed Effects Panel Regression Results-Full Sample

\begin{tabular}{|c|c|c|c|c|}
\hline & (1) & $(2)$ & (3) & (4) \\
\hline \multirow[b]{2}{*}{ Initial GDP per capita } & $-.00045^{* *}$ & $-.00044^{* * *}$ & $-.00043^{* *}$ & $-.00042^{* * *}$ \\
\hline & {$[.00015]$} & [.00011] & {$[.00015]$} & {$[.0001]$} \\
\hline \multirow{2}{*}{$\begin{array}{l}\text { Trend growth rate of working-age } \\
\text { population }\end{array}$} & $1.599^{\text {nth }}$ & $1.635^{\text {ntw }}$ & $1.594^{207}$ & $1.631^{n+1 \times+2}$ \\
\hline & {$[.2902]$} & {$[.2001]$} & {$[.2892]$} & [.1949] \\
\hline \multirow{2}{*}{ Technology gap with the US } & $.0911^{*}$ & $.0915^{*}$ & $.0880^{*}$ & $.0882^{*}$ \\
\hline & {$[.0510]$} & {$[.0445]$} & {$[.0480]$} & {$[.0404]$} \\
\hline \multirow{2}{*}{ Gross enrollment ratio, tertiary level } & $0.1629^{\text {atk }}$ & $.1719^{* \text { tat }}$ & $.1600^{*+1}$ & $.1679^{*+1+4}$ \\
\hline & {$[.0241]$} & {$[.02360]$} & {$[.0252]$} & {$[.0254]$} \\
\hline \multirow{2}{*}{$\begin{array}{l}\text { Squared terms of gross enrollment ratio, } \\
\text { tertiary level }\end{array}$} & -.0016 & $-.00163^{*}$ & $-.0015^{* 11}$ & -.0016 \\
\hline & {$[.00035]$} & .00036 & {$[.0004]$} & {$[.0004]$} \\
\hline \multirow{2}{*}{ Labor market rigidity } & $-2.611^{\text {xit }}$ & $-2.7838^{* * * \pi}$ & $-2.661^{\text {X) }}$ & $-2.818^{\text {kकx }}$ \\
\hline & {$[0.7635]$} & {$[.8006]$} & {$[.7523]$} & {$[.7768]$} \\
\hline \multirow{2}{*}{ Index of voice and accountability } & .9470 & .7945 & 1.0410 & .9155 \\
\hline & {$[1.160]$} & {$[1.4800]$} & [1.1271] & [1.4324] \\
\hline \multirow{2}{*}{ Government efficiency } & $1.588^{*}$ & $1.5016^{\star * t}$ & $1.5706^{*}$ & $1.491^{\text {t*x }}$ \\
\hline & [.7438] & {$[.6350]$} & {$[.7272]$} & [.6212] \\
\hline \multirow{2}{*}{ Trade openness } & $.0670^{* 17}$ & $.0667^{*}$ & $.0638^{\text {sth }}$ & $.06307^{*+1+4}$ \\
\hline & {$[.0112]$} & {$[.0115]$} & [.01292] & [.0134] \\
\hline \multirow{2}{*}{ Squared terms of trade openness } & $-.00009^{\text {*kth }}$ & $-.00008^{* * x+4}$ & $-.00007^{*}$ & $-.00007^{*}$ \\
\hline & {$[.00002]$} & {$[.00002]$} & {$[.00003]$} & {$[.00003]$} \\
\hline \multirow{2}{*}{ Financial Integration } & .0027 & .00294 & .0035 & .00393 \\
\hline & {$[.0022]$} & {$[.0026]$} & {$[.0035]$} & {$[.0041]$} \\
\hline \multirow[b]{2}{*}{ Post GFC dummy variable } & -2.5284 & $-2.541^{*}$ & -2.5536 & $-2.565^{* * *+1}$ \\
\hline & [.3262] & [.3333] & [.3287] & [.3379] \\
\hline
\end{tabular}


Table 2 continued

\begin{tabular}{|c|c|c|c|c|}
\hline & (1) & (2) & (3) & (4) \\
\hline $\begin{array}{l}\text { Technology gap with the US x Political } \\
\text { stability index }\end{array}$ & $\begin{array}{l}-.0061^{*} \\
{[.0510]}\end{array}$ & & $\begin{array}{r}-.00572^{*} \\
{[.0028]}\end{array}$ & \\
\hline $\begin{array}{l}\text { Technology gap with the US } \times \text { Voice and } \\
\text { accountability index }\end{array}$ & & $\begin{array}{r}-.00364 \\
{[.0143]} \\
\end{array}$ & & $\begin{array}{l}-.0037 \\
{[.0150]} \\
\end{array}$ \\
\hline $\begin{array}{l}\text { Financial integration } x \text { Regulatory quality } \\
\text { index }\end{array}$ & $\begin{array}{r}-.00185^{*} \\
{[.0011]} \\
\end{array}$ & $\begin{array}{l}-.00196 \\
.00131]\end{array}$ & & \\
\hline Financial integration $x$ Rule of law index & & & $\begin{array}{r}-.00224 \\
{[.0018]}\end{array}$ & $\begin{array}{l}-.0025 \\
{[.0022]}\end{array}$ \\
\hline $\mathrm{R}^{2}$ & 0.419 & 0.417 & 0.419 & 0.418 \\
\hline$p$-value for Ho: $\beta_{1}=1$ & 0.085 & 0.019 & 0.0859 & 0.018 \\
\hline Number of countries ${ }^{a}$ & 61 & 61 & 61 & 61 \\
\hline Number of observations & 425 & 425 & 425 & 425 \\
\hline
\end{tabular}

GDP = gross domestic product, GFC = global financial crisis, US = United States.

a Countries included in the sample: Argentina, Australia, Austria, Azerbaijan, Bangladesh, Belgium, Bolivia, Brazil, Cambodia, Canada, People's Republic of China, Colombia, Costa Rica, Czech Republic, Denmark, Dominican Republic, Ecuador, Estonia, Finland, France, Germany, Greece, Hungary, Iceland, India, Indonesia, Ireland, Israel, Italy, Japan, Kazakhstan, Republic of Korea, Malaysia, Mexico, Morocco, the Netherlands, New Zealand, Norway, Pakistan, Panama, Peru, Philippines, Poland, Portugal, Qatar, Saudi Arabia, Singapore, Slovenia, South Africa, Spain, Sri Lanka, Sweden, Switzerland, Tajikistan, Thailand, Turkey, United Kingdom, United States, Uruguay, Uzbekistan, and Viet Nam.

Notes: (i) ${ }^{* * *}$ - significant at $0.01 ;^{* *}$ - significant at $0.05 ;$ - significant at 0.1; (ii) numbers in brackets are standard errors of the coefficient estimate.

Source: Authors' estimates.

The Harrod-Domar definition that the natural or potential output growth rate is equal to the growth rates of the labor force and labor productivity implies that the coefficient of the trend growth rate of working-age population should be equal to 1 . We test the null hypothesis $H_{0}: \beta_{1}=1$ coefficient estimates for the trend growth rate of working-age population and fail to reject it at the $5 \%$ level of significance for specifications (1) and (3) and at the $1 \%$ level of significance in specifications (2) and (4). ${ }^{24}$ This outcome is consistent with the definition of potential output growth used in this paper and indicates that the trend growth rate of working-age population is a good proxy variable for long-run labor force growth.

In line with expectations, our proxy for the technology gap with the US has a positive coefficient estimate. ${ }^{25}$ The coefficient estimates in all four specifications in Table 2 are all statistically significant at the 10\% confidence level and have values approximately equal to .09. This implies that a 1 percentage point increase in the technology gap with the US increases potential output growth by 09 percentage points. This positive impact is consistent with the view that larger technology gaps foster potential output growth via the productivity gains associated with technology transfers.

We find evidence of nonlinearity in the impact of the tertiary gross enrollment ratio on potential output growth. At sufficiently low levels, the marginal impact of the tertiary gross enrollment ratio on potential output growth is positive, but its effects decline with each percentage point increase in the share of population with tertiary education. At some threshold value, the marginal impact of the tertiary enrollment ratio on potential output growth falls to 0 . From Equation (6), the marginal impact of the gross enrollment ratio on potential output growth is given by:

24 The $p$-values for the t-test are shown in the third to the last row of Table 2.

25 The technology gap proxy variable is computed as 1 minus the ratio of an economy's labor productivity and the US labor productivity. If a country has labor productivity similar to that of the US, the gap variable is zero. If a country has lower labor productivity, the gap variable is positive and vice versa if the country has higher labor productivity relative to the US. 


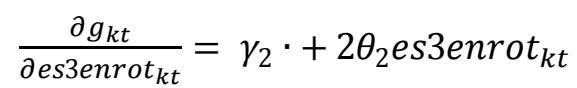

so that the threshold enrollment ratio is equal to $\frac{-\gamma_{2}}{2 \theta_{2}}$. Given the estimates of the coefficients of the enrollment ratio and its squared terms, the average threshold value of the enrollment ratio is $50.91 \%$ for specification $1 .{ }^{26}$ For values of the enrollment ratio above the threshold, the marginal impact on potential output growth becomes increasingly negative. ${ }^{27}$ This is shown graphically Figure 2.

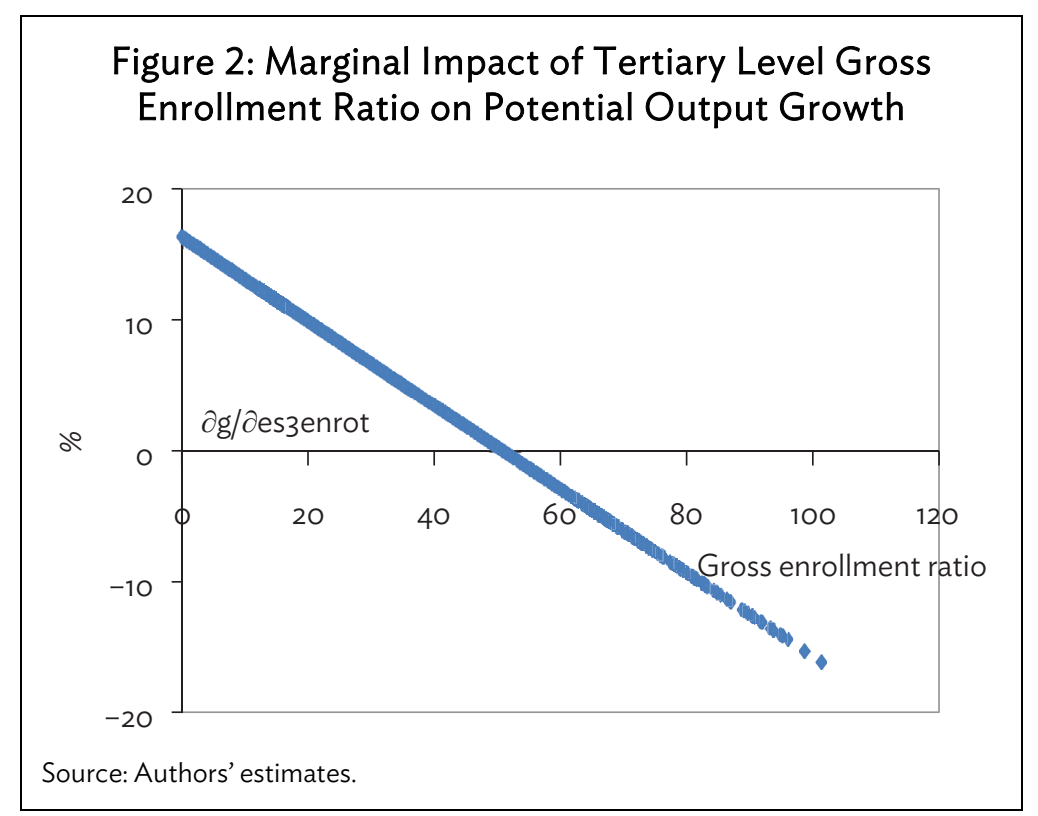

Similar to the tertiary level gross enrollment ratio, we find evidence of nonlinearity for the impact of trade openness on potential output growth. The marginal impact of a 1 percentage point increase in the ratio of total exports and imports relative to GDP is positive at relatively low levels, but it is decreasing as the degree of trade openness rises. From Equation (6), we can write the marginal impact of trade openness on potential output growth as:

$$
\frac{\partial g_{k t}}{\partial \text { trade }_{k t}}=\gamma_{1} \cdot+2 \theta_{1} \text { trade }_{k t}
$$

This implies that the threshold trade openness ratio is $\frac{-\gamma_{1}}{2 \theta_{1}}$.

Note from Table 2, however, that the coefficient of the squared terms of trade openness is negative and very small so that the marginal impact of increased trade openness declines very slowly. The coefficient estimates imply that a 1 percentage point increase in the ratio of tradables to GDP is associated to an increase in potential output growth by approximately $0.07 \%$ at low levels of trade

26 Specification (2) has a threshold value of $52.7 \%$ for the tertiary level gross enrollment ratio, while specifications (3) and (4) have threshold values of $53.3 \%$ and $52.5 \%$, respectively.

27 Since the estimates of $\gamma_{2}$ and $\theta_{2}$ are stochastic, we test the statistical significance of $\frac{\partial g_{k t}}{\partial e s 3 e n r o t_{k t}}=\gamma_{2} \cdot 2 \theta_{2} e s 3 e n r o t_{k t}$ for all values of es 3 enrot $_{k t}$ and find that it is only statistically significant for values of es 3 enrot $_{k t}$ below $41 \%$. 
openness. As trade openness increases, its marginal impact on potential output growth gradually decreases until it reaches zero at a threshold value of trade openness. Based on specifications (1) and (3) in Table 2, we estimate the threshold level of trade openness at $372 \%$ and $455 \%$, respectively. The marginal impact of trade openness under specification (1) is presented in Figure 3.

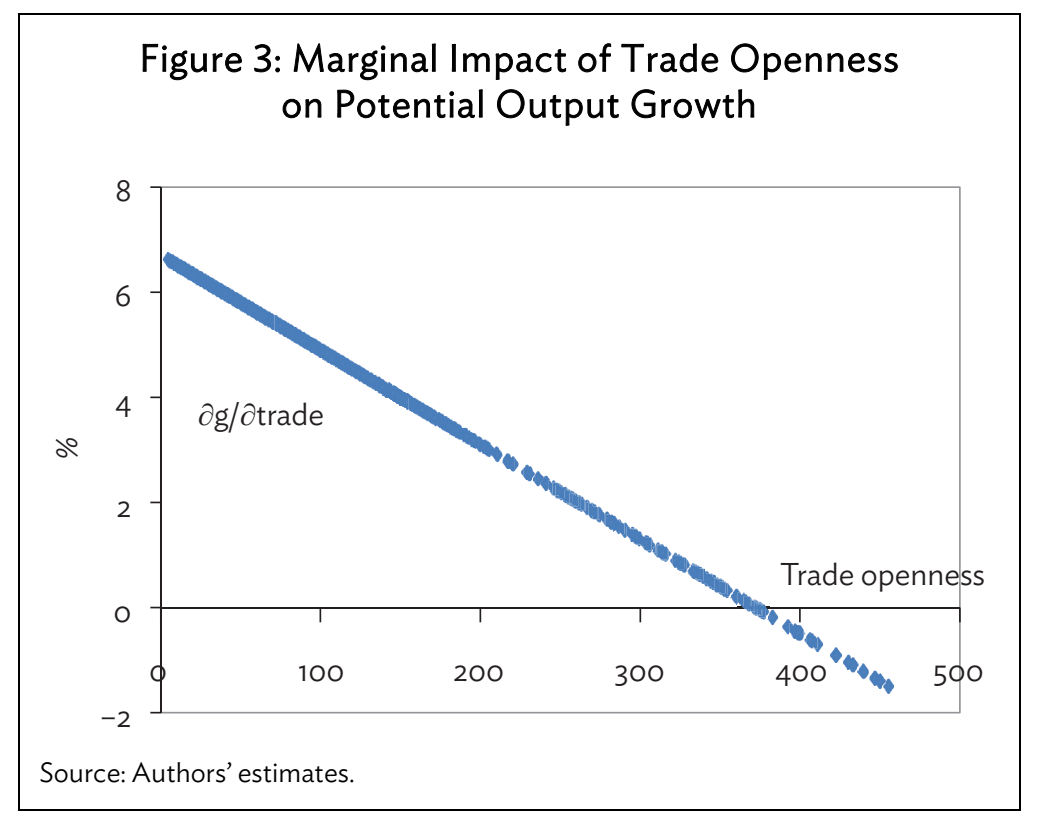

The index of labor market rigidity has a negative and highly significant impact on the growth of potential output. This is consistent with the hypothesis that less flexible labor markets can hamper long-term or potential growth. Each specification in Table 2 shows that the estimated coefficient of the labor market rigidity index is slightly over -2.6 such that a 1-point increase in the value of the labor market rigidity decreases potential output growth by approximately 2.6 to 2.8 percentage points depending on the specification used. Since the labor market rigidity index has a range of 0-3.5, the maximum reduction in potential output growth due to inflexible labor market arrangements is approximately 9.8 percentage points, holding all other determinants constant.

The index of voice and accountability has statistically insignificant effects on potential output growth. In contrast, the index of government efficiency has a positive and statistically significant effect on the growth of potential output in all specifications of Equation (6). Recall that the index values are $z$-scores such that these are expressed in terms of the number of standard deviations away from zero. ${ }^{28} \mathrm{~A}$ one standard deviation increase in the index of government efficiency raises potential output growth by approximately 1.5 to 1.6 percentage points.

The panel regression results also point to the significance of interactions between institutional quality indicators and other robust determinants of potential output growth. The measure for the degree of financial integration, for example, negatively affects potential output growth if an interaction term between financial integration and regulatory quality or rule of law index is not included in the specification. ${ }^{29}$ We correct this counterintuitive result by adding an interaction term between financial

\footnotetext{
28 The voice and accountability and government efficiency indexes are derived annually from a cross-section of countries that are different from the list of countries in our data set. See Kaufmann, Kraay, and Ziodo-Lobaton (1999) for details.

29 See Appendix 5.
} 
integration and regulatory quality in specifications 1 and 2 in Table 2, and an interaction term between financial integration and the index for the rule of law in specifications 3 and 4 in the same table. By adding the interaction terms, we obtain positive coefficient estimates, albeit statistically insignificant, for the financial integration index and negative coefficient estimates for the interaction terms. The marginal impact of greater financial integration is positive but is decreasing with increased regulatory efficiency or adherence to the rule of law. From Equation (6), we note that with the interaction term with regulatory quality, an increase in financial integration has the following total marginal impact on potential output growth:

$$
\frac{\partial g_{k t}}{\text { integr_index }_{k t}}=\gamma_{4} \cdot+\alpha_{2} \cdot r e g q_{k t}
$$

Using the coefficient estimates in column 3 of Table 2, Equation 9 is represented graphically in Figure 4:

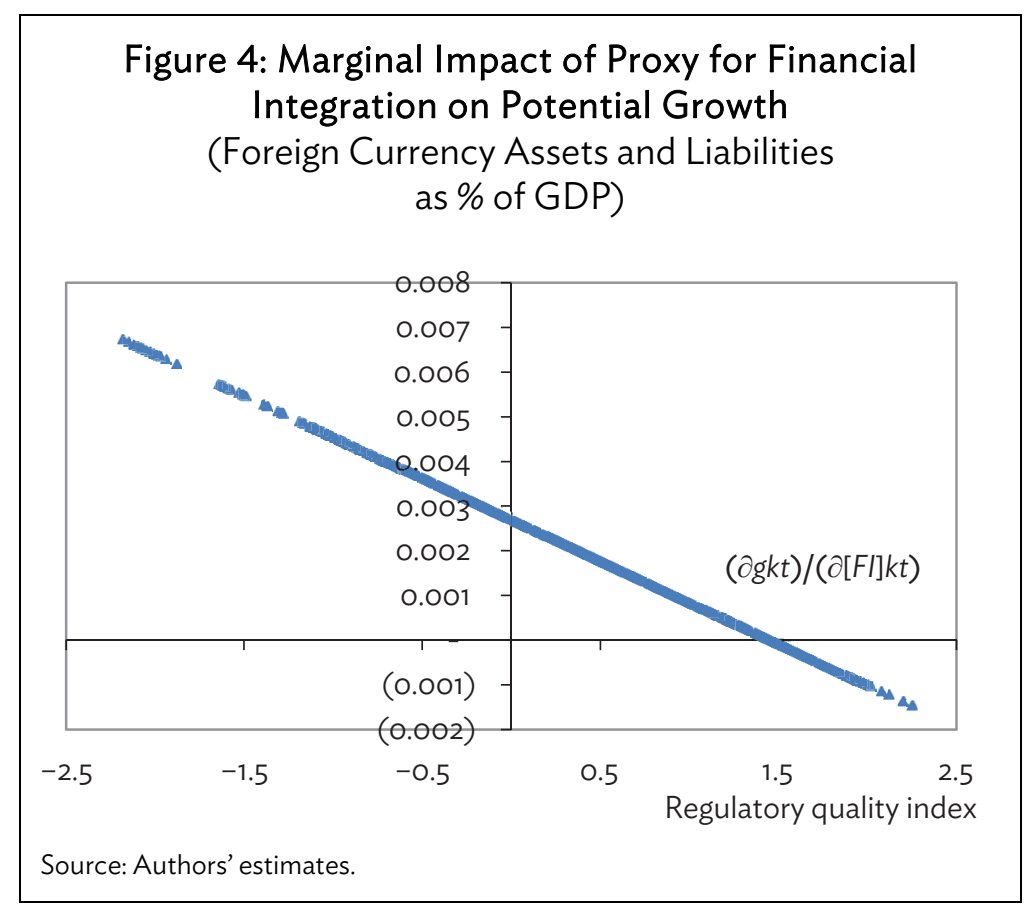

The marginal impact of financial integration reaches its threshold when the regulatory quality index is 1.459 standard deviations away from the mean. Beyond that level of regulatory efficiency, the marginal impact of greater financial integration on potential output growth becomes negative given the negative coefficient estimate of the interaction term between financial integration and regulatory quality. Our findings are aligned to those of Law and Singh (2014), who show that finance is beneficial to output growth up to a certain threshold. Beyond that threshold level, finance begins to crowd out real output growth. Our findings support the notion of a threshold level of financial integration, and that the threshold is partially dictated by the interaction of financial integration and the quality of institutions. $^{30}$

30 See Kose et al. (2006) for a discussion on the possibility of interaction between financial globalization and quality of institutions in the determination of threshold conditions on output growth and volatility. 
We likewise allow the technology gap with the US to interact with two other institutional quality indicators; namely the index of political stability and the voice and accountability index. The results for these interaction terms are found in specifications (1) and (3) in Table 2. The coefficients of the interaction terms between the technology gap with the US and the index of political stability are negative and statistically significant, indicating that the marginal gains in potential output growth arising from a larger technology gap is declining as the index of political stability increases. ${ }^{31}$ As observed for the interaction between financial integration and regulatory quality, the interaction of the technology gap and political stability points to the existence of a threshold for the marginal gains from the technology gaps. The marginal impact on potential output growth due to a reduction in country k's technology gap with the US is characterized by Equation 10.

$$
\frac{\partial g_{k t}}{\partial g a p_{k t}}=\gamma_{3} \cdot+\alpha_{1} \cdot \text { polstab }_{k t}
$$

Given the coefficient estimates in column 1 of Table 2, Equation 11 is graphically depicted in Figure 5:

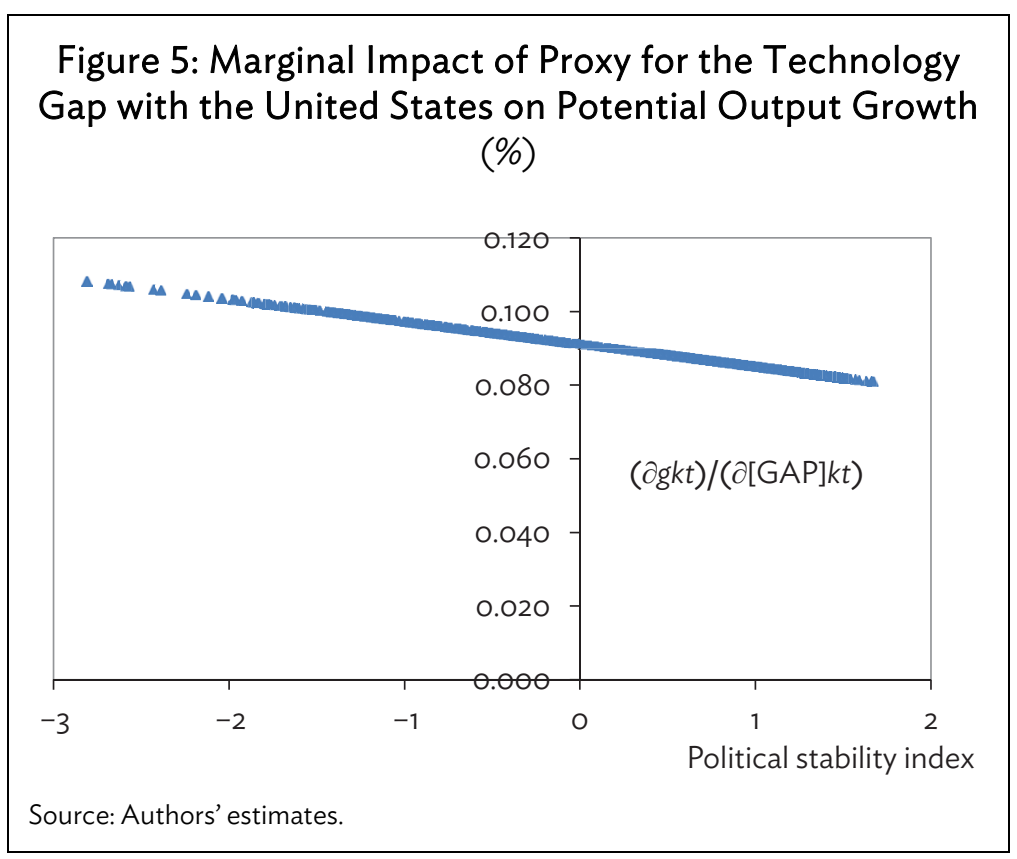

Note that while the marginal impact of reducing the technology gap is declining as the index for political stability is rising, it does not reach zero at the maximum value of the political stability index. Given our coefficient estimates in column 1 of Table 2, the implied threshold value of the political stability index is 15 standard deviations away from the mean. Note that by construction, the political stability index has a maximum value of 2.5 such that the marginal impact of the technology gap will always be positive. ${ }^{32}$

31 Recall that higher technology gaps translate to larger potential growth arising from technology transfers.

32 That is, when the political stability index has a $z$-value of 15 , the rate of change of potential output growth relative to marginal changes in the technology gap is zero. Since polstab, by construction, has a maximum value of 2.5 , the marginal impact of reducing the technology gap will always be positive. 
The results of our panel regressions also indicate that the growth path of potential output after the GFC shifted downward by an average of $2.5 \%$ for countries in our sample. This suggests that the GFC has a statistically significant and persistent effect on the trajectory of potential output growth for the economies in our sample.

\section{B. Spillover Effects of the Growth of the People's Republic of China and the United States}

To test whether the actual output growth of the US and the PRC have spillover effects on potential output growth of countries included in our sample, we include the actual output growth of the US and the PRC in the list of regressors in Equation (6).

$$
g_{k t}=\mu_{k}+\beta_{1} g d p p c_{-} y o_{k t}+\beta_{2} g_{-} w_{\text {ap }} t r_{k t}+\beta_{3} \text { lamrig }_{k t}+\beta_{4} \text { voa }_{k t}+\beta_{5} \text { goveff }_{k t}+
$$

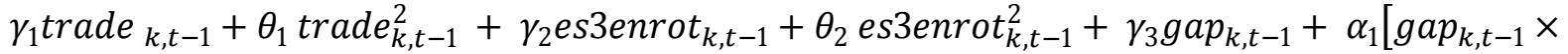
inst $\left._{k, t-1}\right]+\gamma_{4}$ integr_index $_{k, t-1}+\alpha_{2}\left[\right.$ integr_index $_{k, t-1} \times$ inst $\left._{k, t-1}\right]+\gamma_{5} G F C_{t}+\gamma_{6} g_{P R C}+$ $\gamma_{7} g_{U S A}+\epsilon_{k t}$

where $g_{P R C}$ and $g_{U S A}$ are the actual output growth rates of the PRC and the US, respectively. The results of the fixed effects panel regression estimation procedure for Equation 12 are presented in Table 3.

Table 3: Fixed Effects Panel Regressions Results-Spillover Effects of the Growth of the People's Republic of China and the United States

\begin{tabular}{|c|c|c|c|c|}
\hline & (1) & $(2)$ & (3) & (4) \\
\hline \multirow{2}{*}{ Initial GDP per capita } & -.0004 & -.00038 & -.00038 & $-.00037^{* x}$ \\
\hline & {$[.0002]$} & {$[.00013]$} & {$[.0002]$} & {$[.0001]$} \\
\hline \multirow{2}{*}{$\begin{array}{l}\text { Trend growth rate of working-age } \\
\text { population }\end{array}$} & $1.3015^{n+1}$ & 1.3299 & 1.3027 & $1.327^{2 \times 1+2}$ \\
\hline & {$[.2234]$} & {$[.16251]$} & {$[.2184]$} & [.15489] \\
\hline \multirow{2}{*}{ Technology gap with the US } & .0921 & $.0925^{* 10}$ & .0895 & .08972 \\
\hline & {$[.04575]$} & {$[.03904]$} & {$[.0445]$} & {$[.03672]$} \\
\hline \multirow{2}{*}{ Gross enrollment ratio, tertiary level } & .08896 & .09483 & .0859 & .09070 \\
\hline & {$[.07000]$} & {$[.07323]$} & {$[.0710]$} & {$[.0733]$} \\
\hline \multirow{2}{*}{$\begin{array}{l}\text { Squared terms of gross enrollment ratio, } \\
\text { tertiary level }\end{array}$} & -.0011 & $-.0011^{*}$ & -.0010 & -.0011 \\
\hline & {$[.0005]$} & {$[.00051]$} & {$[.0005]$} & {$[.0005]$} \\
\hline \multirow{2}{*}{ Labor market rigidity } & -2.922 & -3.035 & -2.929 & -3.0232 \\
\hline & {$[.70688]$} & {$[.8444]$} & {$[.6983]$} & {$[.8286]$} \\
\hline \multirow{2}{*}{ Index of voice and accountability } & 1.0059 & .9217 & 1.054 & .9840 \\
\hline & {$[.8621]$} & [.1916] & {$[.8277]$} & [1.1509] \\
\hline \multirow{2}{*}{ Government efficiency } & 1.7617 & 1.7156 & $1.7528^{* *}$ & 1.7130 \\
\hline & {$[.4547]$} & [.3533] & {$[.4438]$} & {$[.3412]$} \\
\hline \multirow{2}{*}{ Trade openness } & .0573 & .0572 & 0543 & .0539 \\
\hline & {$[.0084]$} & {$[.0084]$} & {$[.0112]$} & {$[.01102]$} \\
\hline \multirow{2}{*}{ Squared terms of trade openness } & -.00006 & -.00006 & -.00005 & $-.00005^{*}$ \\
\hline & {$[.00002]$} & {$[.00002]$} & {$[.00003]$} & {$[.00003]$} \\
\hline \multirow{2}{*}{ Financial integration } & -.00065 & -.00056 & .00061 & .0008 \\
\hline & {$[.0021]$} & {$[.0023]$} & {$[.0034]$} & {$[.0036]$} \\
\hline \multirow{2}{*}{ Post GFC dummy variable } & $-1.8457^{2 k \pi t}$ & -1.8230 & -1.8466 & $-1.8269^{* x+1}$ \\
\hline & {$[.4222]$} & [.4146] & {$[.4311]$} & [.4265] \\
\hline \multirow{2}{*}{$\begin{array}{l}\text { Technology gap with the US x Political } \\
\text { stability index }\end{array}$} & -.00399 & & -.00344 & \\
\hline & {$[.0056]$} & & {$[.00562]$} & \\
\hline
\end{tabular}


Table 3 continued

\begin{tabular}{|c|c|c|c|c|}
\hline & (1) & $(2)$ & (3) & (4) \\
\hline $\begin{array}{l}\text { Technology gap with the US } \times \text { Voice and } \\
\text { accountability index }\end{array}$ & & $\begin{array}{r}-.0033 \\
{[.01227]}\end{array}$ & & $\begin{array}{l}-.0028 \\
{[.0127]}\end{array}$ \\
\hline $\begin{array}{l}\text { Financial integration } x \text { Regulatory quality } \\
\text { index }\end{array}$ & $\begin{array}{r}-.00094 \\
{[.0010]} \\
\end{array}$ & $\begin{array}{r}-.00098 \\
{[.0011]} \\
\end{array}$ & & \\
\hline Financial integration $x$ Rule of law index & & & $\begin{array}{l}-.00162 \\
{[.00173]}\end{array}$ & $\begin{array}{r}-.0017 \\
{[.0019]} \\
\end{array}$ \\
\hline Actual output growth of the US & $\begin{array}{l}.3535^{* *} \\
{[.1351]}\end{array}$ & $\begin{array}{l}.3656^{*} \\
{[.1191]}\end{array}$ & $\begin{array}{l}.3562 \\
{[.1372]}\end{array}$ & $\begin{array}{l}.3666^{* *} \\
{[.1204]}\end{array}$ \\
\hline Actual output growth of the PRC & $\begin{array}{l}.1997^{* 171} \\
{[.0353]}\end{array}$ & $\begin{array}{l}.1959 \\
{[.0406]}\end{array}$ & $\begin{array}{l}.1994 \\
{[.0364]}\end{array}$ & $\begin{array}{l}.1961 \\
{[.0421]}\end{array}$ \\
\hline $\mathrm{R}^{2}$ & 0.475 & 0.474 & 0.475 & 0.475 \\
\hline$p$-value for Ho: $\beta_{1}=1$ & 0.226 & 0.09 & 0.215 & 0.08 \\
\hline Number of countries $^{a}$ & 61 & 61 & 61 & 61 \\
\hline Number of observations & 425 & 425 & 425 & 425 \\
\hline
\end{tabular}

GDP = gross domestic product, $\mathrm{GFC}=$ global financial crisis

Notes: (i) ${ }^{* * *}$ - significant at $0.01 ;^{* *}$ - significant at $0.05 ;^{*}$ - significant at 0.1 ; (ii) numbers in brackets are standard errors of the coefficient estimate.

a Countries included in the sample: Argentina, Australia, Austria, Azerbaijan, Bangladesh, Belgium, Bolivia, Brazil, Cambodia, Canada, Colombia, Costa Rica, Czech Republic, Denmark, Dominican Republic, Ecuador, Estonia, Finland, France, Germany, Greece, Hungary, Iceland, India, Indonesia, Ireland, Israel, Italy, Japan, Kazakhstan, Republic of Korea, Malaysia, Mexico, Morocco, the Netherlands, New Zealand, Norway, Pakistan, Panama, Peru, Philippines, Poland, Portugal, Qatar, Saudi Arabia, Singapore, Slovenia, South Africa, Spain, Sri Lanka, Sweden, Switzerland, Tajikistan, Thailand, Turkey, United Kingdom, Uruguay, Uzbekistan, and Viet Nam Source: Authors' estimates.

Increases in the actual output growth of the US and PRC have positive and statistically significant spillover effects on our sample of countries. However, an increase in the US actual output growth has a higher impact on the potential output growth of other economies. Specifically, a 1 percentage point increase in the US potential output growth increases the potential output growth of other economies by $0.35-0.36$ percentage points. A similar increase in the PRC's actual output growth only increases other economies' potential output growth by 0.20 percentage points.

\section{THE IMPACT OF REFORMS ON POTENTIAL OUTPUT GROWTH IN ASIA}

The results of our econometric analysis in Table 1 shows that potential output growth exhibit a persistent decline of approximately 2.5 percentage points after the GFC. In addition, forecasts of longrun working-age population growth over the next 10 years indicate that demographic dividends are decelerating in most developing and emerging countries in Asia. ${ }^{33}$ Recall that potential output growth is the sum of the growth of the labor force and labor productivity. Consequently, the decelerating growth of working-age population in Asia imposes an additional downward pressure on potential output growth in the region. Can policy interventions that target the other determinants of potential output growth compensate for the negative effects of the GFC and declining demographic dividends in Asia? Specifically, can reforms aimed toward reducing labor market rigidity, increasing tertiary enrollment ratios, enhancing trade openness and financial market integration, and improving governance effectiveness, and voice and accountability offset the projected decline in long-run working-age population growth rates in Asia?

33 The weighted average of working-age population in developing and emerging Asia is expected to decline at -0.67 percentage points per annum during 2016-2025. 
We conduct a policy impact simulation using the results of our econometric analysis found in Table 1 for a sample of developing and emerging economies in Asia. ${ }^{34}$ For this simple exercise, we focus on the overall impact of reforms over a 10-year period, making no assumptions regarding the pace at which the gap to the frontier could be reduced annually. Our aim here is not to forecast the possible annual impact of the reforms taken into account but, more generally, to provide a broad picture for the possible gains from such reforms over a reasonable time horizon. As such, our simulation does not produce an estimate of the year-by-year, cumulative effect of the reforms - rather, the average impact values (presented in Table 4) represent the simple annual average of the overall impact of the reforms, calculated for the 10-year period considered.

We assume that the correct policy mix and sequencing are implemented in a manner such that potential output growth is positively affected by all policy reforms. For this exercise, we define the determinants' frontier values as values that provide the maximum positive impact on potential output growth.

Recall that the proxy variables for governance effectiveness and voice accountability have maximum values of 2.5. Since they positively influence potential output growth, we assign this upper bound of its range of values as the frontier of these variables. In contrast, we note that labor market rigidity negatively affects potential output growth so that we set its frontier value at the lower bound of its range of values, which is zero. For the tertiary education ratio and trade openness, we set their respective frontier values at their threshold levels of $51 \%$ and $450 \%$, respectively. We then assume that reforms will close the gap between the 2015 levels of the determinants of potential output growth and their respective frontier values by $50 \%$ over 10 years. Since trade openness has a very high threshold value, we assume that it will only increase by 25 percentage points over 10 years. A similar assumption is made for financial market integration.

Note from Table 4 that we have also added the half of the average annual deceleration of working-age population growth in the column under demographic effects. We are assuming that developing and emerging countries will be able to partially mitigate the decline in labor force growth with programs that boost labor force participation. As such, the demographic effect of an average decline of -0.67 percentage points in the growth of working-age population is reduced to -0.33 percentage points.

Table 4 also shows that the marginal impact of reforms that close the gap to the frontier by half within the next decade is projected to raise potential output growth in developing and emerging Asia by an average of 0.98 percentage points. The impact of the assumed reforms is more than sufficient to fully offset the expected slowdown in potential output growth due to demographic effects.

34 We include Azerbaijan; Bangladesh; Cambodia; the PRC; Hong Kong, China; India; Indonesia; Japan (not included in computing the regional average); Kazakhstan; the Republic of Korea; Malaysia; Pakistan; the Philippines; Singapore; Sri Lanka; Taipei,China; Tajikistan; Thailand; Turkmenistan; Uzbekistan; and Viet Nam in the simulation. 
Table 4: Average Incremental Potential Output Growth (Percentage points)

\begin{tabular}{|c|c|c|c|c|c|c|c|c|}
\hline \multirow[b]{2}{*}{ Economy } & \multicolumn{5}{|c|}{ Areas of Reform } & \multirow[b]{2}{*}{$\begin{array}{c}\text { Total } \\
\text { Reforms }\end{array}$} & \multirow[b]{2}{*}{$\begin{array}{l}\text { Demo- } \\
\text { graphic } \\
\text { Effect }\end{array}$} & \multirow[b]{2}{*}{ Total } \\
\hline & $\begin{array}{c}\text { Tertiary } \\
\text { Enrollment }\end{array}$ & $\begin{array}{l}\text { Labor } \\
\text { Market } \\
\text { Rigidity }\end{array}$ & $\begin{array}{c}\text { Institutional } \\
\text { Quality }\end{array}$ & $\begin{array}{c}\text { Trade } \\
\text { Openness }\end{array}$ & $\begin{array}{c}\text { Financial } \\
\text { Integration }\end{array}$ & & & \\
\hline Azerbaijan & 0.26 & 0.30 & 0.52 & 0.16 & 0.01 & 1.25 & -1.01 & 0.24 \\
\hline Bangladesh & 0.30 & 0.23 & 0.47 & 0.16 & 0.02 & 1.17 & -0.01 & 1.16 \\
\hline Cambodia & 0.31 & 0.23 & 0.52 & 0.16 & 0.01 & 1.23 & -0.31 & 0.92 \\
\hline PRC & 0.21 & 0.20 & 0.51 & 0.16 & 0.01 & 1.08 & -0.34 & 0.74 \\
\hline Hong Kong, China & N.A. & N.A. & 0.20 & 0.00 & 0.00 & 0.20 & -0.59 & -0.38 \\
\hline India & 0.27 & 0.27 & 0.36 & 0.16 & 0.01 & 1.07 & -0.13 & 0.94 \\
\hline Indonesia & 0.23 & 0.23 & 0.39 & 0.16 & 0.01 & 1.01 & -0.11 & 0.90 \\
\hline$J_{a p a n}{ }^{a}$ & 0.00 & 0.06 & 0.18 & 0.16 & 0.00 & 0.40 & 0.00 & 0.40 \\
\hline Kazakhstan & 0.03 & 0.32 & 0.51 & 0.16 & 0.01 & 1.04 & -0.63 & 0.41 \\
\hline Republic of Korea & 0.00 & 0.15 & 0.24 & 0.16 & 0.00 & 0.55 & -0.41 & 0.14 \\
\hline Malaysia & 0.12 & 0.14 & 0.33 & 0.16 & 0.01 & 0.75 & -0.38 & 0.38 \\
\hline Pakistan & 0.32 & 0.13 & 0.50 & 0.16 & 0.02 & 1.12 & -0.20 & 0.92 \\
\hline Philippines & 0.15 & 0.22 & 0.37 & 0.16 & 0.01 & 0.91 & -0.26 & 0.65 \\
\hline Singapore & 0.01 & 0.13 & 0.23 & 0.16 & 0.00 & 0.52 & -0.93 & -0.41 \\
\hline Sri Lanka & 0.13 & 0.21 & 0.44 & 0.16 & 0.01 & 0.95 & 0.19 & 1.14 \\
\hline Taipei,China & N.A. & 0.31 & 0.22 & N.A. & 0.00 & 0.54 & -0.65 & -0.11 \\
\hline Tajikistan & 0.23 & 0.20 & 0.57 & 0.16 & 0.02 & 1.17 & -0.43 & 0.74 \\
\hline Thailand & 0.06 & 0.21 & 0.40 & 0.16 & 0.01 & 0.84 & -0.33 & 0.51 \\
\hline Turkmenistan & N.A. & 0.13 & 0.65 & 0.16 & 0.03 & 0.96 & -0.32 & 0.64 \\
\hline Uzbekistan & 0.28 & 0.21 & 0.60 & 0.16 & 0.02 & 1.26 & -0.87 & 0.40 \\
\hline $\begin{array}{l}\text { Weighted } \\
\text { Average }^{b}\end{array}$ & & & & & & 0.98 & -0.33 & 0.65 \\
\hline
\end{tabular}

PRC = People's Republic of China.

Note: Assumes that reforms will close 50\% of the gap between 2015 values of determinants and their frontier values.

a Excluded from the computation of the weighted average

$g$ Uses the GDP shares of the listed countries as weights

Source: Authors' calculations.

\section{CONCLUSION}

The results of our BMA analyses show that in addition to the long-run growth of working-age population, the tertiary gross enrollment ratio, the technology gap with the US, labor market rigidity, trade and financial openness, and institutional quality significantly affect the growth of potential output. Of the 34 possible determinants of potential output growth that we examined, nine are robust determinants of potential output growth based on our series of BMA analyses on a sample of 70 economies. Of these nine robust determinants, three are variables typically associated to traditional growth theory, two are trade and financial openness variables, and three are indicators of institutional quality.

Our fixed effects panel regression analyses of potential output growth based on a subsample of 61 economies and the nine robust determinants selected via our BMA analysis shows that potential output growth is nonlinear in tertiary education and trade openness. Specifically, potential output growth is an inverted $U$-shaped function of the tertiary enrollment ratio and trade openness. The marginal impact of these variables on potential output growth is positive at low levels but decreases as tertiary education and trade openness increase. We also find evidence that financial integration and 
the technology gap with the US interact with institutional quality variables such that the marginal effects of increased financial integration and reductions in the technology gap are attenuating with the quality of institutions.

The results of our panel regression analyses are in line with Harrod's definition of potential output growth. The Wald tests for the coefficient estimates of the long-run growth of working-age population could not reject the null hypothesis that they have values equal to unity. This suggests that economies will always achieve proportionally higher potential output growth as demographic conditions improve. From a policy perspective, economies with aging populations could still gain incremental potential output growth by providing incentives for greater labor force participation and opening their labor markets to skilled migrant workers.

The high degree of collinearity between some of the robust and nonrobust determinants of potential output growth is not just a technical nuance that affects the qualities of our estimates, but is a reflection of the interrelationships between determinants of potential output growth. Furthermore, the nonlinearity of effects of some determinants and the presence of interaction effects between institutional quality variables and the degree of financial integration and technology gap highlight the importance of the proper sequencing of policy reforms. In some cases, reforms aimed at reducing trade barriers and labor market rigidity are complementary and need to be done in tandem to allow adjustments in both product and factor markets. Increased financial integration, on the other hand, requires prior liberalization of domestic financial markets and the development of an efficient regulatory system for financial intermediaries to mitigate macro financial stability risks associated with more open capital flows. Our policy simulation shows that reforms could have potent effects on developing and emerging Asia's growth over the long run, and if done correctly could more than offset the unfavorable effects of declining demographic dividends.

We stress that our findings reflect the average behavior of the economies in our sample during 1970-2014, and that the robust determinants of growth resulting from our analyses may be viewed as common factors for all countries. We recognize that each economy has peculiarities that also need to be considered, and that the extent, sequencing, and timing of reform require a thorough examination of these idiosyncrasies. 
APPENDIX 1: ECONOMIES INCLUDED IN THE DATA SET

\begin{tabular}{lll}
\hline High Income & Middle Income & Low Income \\
\hline Argentina & Algeria & Cambodia \\
Australia & Azerbaijan & \\
Austria & Bangladesh & \\
Belgium & Bolivia & \\
Canada & Brazil & \\
Chile & People's Republic of China & \\
Czech Republic & Colombia \\
Denmark & Costa Rica & \\
Estonia & Dominican Republic \\
Finland & Ecuador \\
France & Egypt \\
Germany & India \\
Greece & Indonesia \\
Hong Kong, China & Kazakhstan \\
Hungary & Malaysia \\
Iceland & Mexico \\
Ireland & Morocco \\
Israel & Pakistan \\
Italy & Panama \\
Japan & Peru \\
Republic of Korea & Philippines \\
Luxembourg & South Africa \\
The Netherlands & Sri Lanka \\
New Zealand & Tajikistan \\
Norway & Thailand \\
Poland & Turkey \\
Portugal & Turkmenistan \\
Qatar & Uzbekistan \\
Saudi Arabia & Viet Nam \\
Singapore & \\
Slovak Republic & \\
Slovenia & \\
Spain & \\
Sweden & \\
Switzerland & \\
Taipei,China & \\
United Kingdom & \\
United States & \\
Uruguay & \\
Venezuela & \\
\hline Source:Author'compition. \\
\end{tabular}

Source: Authors' compilation. 


\section{APPENDIX 2: LIST OF VARIABLES, DEFINITIONS, AND SOURCES}

\begin{tabular}{|c|c|c|}
\hline Variable Code & Definition & Source \\
\hline agr_emp_sh & Employment in agriculture (\% of total employment) & $\begin{array}{l}\text { International Labour Organization: Key Indicators of } \\
\text { the Labour Market database; Global Employment } \\
\text { Trends Dataset (2014). Note: Data reported in WDI } \\
\text { too (possibly, incomplete). }\end{array}$ \\
\hline cocorr & $\begin{array}{l}\text { Control of corruption index. Reflects perceptions of } \\
\text { the extent to which public power is exercised for private } \\
\text { gain, including both petty and grand forms of corruption, } \\
\text { as well as "capture" of the state by elites and private } \\
\text { interests. Estimate of governance, it ranges from } \\
\text { approximately - } 2.5 \text { (weak) to } 2.5 \text { (strong) governance } \\
\text { performance. }\end{array}$ & $\begin{array}{l}\text { World Bank's Worldwide Governance Indicators, } 2014 \\
\text { Update }\end{array}$ \\
\hline di16merdt & R\&D expenditures as a percentage of GDP. & $\begin{array}{l}\text { CANA Database (v. Jan 2011). Original source: } \\
\text { UNESCO, OECD, RICYT }\end{array}$ \\
\hline econ_glob & $\begin{array}{l}\text { Index of Economic Globalization, characterized as long } \\
\text { distance flow of goods, capital and services as well as } \\
\text { information and perceptions that accompany market } \\
\text { exchanges. Ranges between } 0 \text { and } 10 \text {, higher values } \\
\text { indicate more globalization. }\end{array}$ & KOF index of globalization \\
\hline es1enrop & $\begin{array}{l}\text { Gross enrollment ratio, Primary. Ratio of total } \\
\text { enrollment, regardless of age, to the population of the } \\
\text { age group that officially corresponds to the primary } \\
\text { level. }\end{array}$ & $\begin{array}{l}\text { CANA Database (v. Jan 2011). Original source: } \\
\text { UNESCO }\end{array}$ \\
\hline es2enros & $\begin{array}{l}\text { Gross enrollment ratio, Secondary. Ratio of total } \\
\text { enrollment, regardless of age, to the population of the } \\
\text { age group that officially corresponds to the secondary } \\
\text { level. }\end{array}$ & $\begin{array}{l}\text { CANA Database (v. Jan 2011). Original source: } \\
\text { UNESCO }\end{array}$ \\
\hline es3enrot & $\begin{array}{l}\text { Gross enrollment ratio, Tertiary. Ratio of total } \\
\text { enrollment, regardless of age, to the population of the } \\
\text { age group that officially corresponds to the tertiary level. }\end{array}$ & $\begin{array}{l}\text { CANA Database (v. Jan 2011). Original source: } \\
\text { UNESCO }\end{array}$ \\
\hline es10schom & $\begin{array}{l}\text { Mean years of schooling. Average number of years of } \\
\text { school completed in population over } 14 \text {. }\end{array}$ & $\begin{array}{l}\text { CANA Database (v. Jan 2011). Original source: Barro } \\
\text { and Lee (2012); World Bank }\end{array}$ \\
\hline es12educe & $\begin{array}{l}\text { Public expenditure on education. Current and capital } \\
\text { public expenditure on education. }\end{array}$ & $\begin{array}{l}\text { CANA Database (v. Jan 2011). Original source: } \\
\text { UNESCO }\end{array}$ \\
\hline es14teacr_plus & $\begin{array}{l}\text { Primary pupil-teacher ratio. Ratio (number of pupils } \\
\text { enrolled in primary school) / (number of primary school } \\
\text { teachers) }\end{array}$ & $\begin{array}{l}\text { CANA Database (v. Jan 2011). Original source: } \\
\text { UNESCO }\end{array}$ \\
\hline fdi_index & $\begin{array}{l}\text { FDI integration index. Sum of the stocks of FDI assets } \\
\text { and liabilities, as \% of GDP. Follows suggestions in Kose } \\
\text { et al. (2006). }\end{array}$ & $\begin{array}{l}\text { Updated and extended version of data set constructed } \\
\text { by Lane and Milesi-Ferretti (2007) }\end{array}$ \\
\hline fin_ref & $\begin{array}{l}\text { Financial reform index by Abiad, Detragiache, and } \\
\text { Tressel (2008). Normalized to be between } 0 \text { and } 1 \text {, } \\
\text { higher values indicate a more liberalized financial } \\
\text { market. }\end{array}$ & Abiad, Detragiache, and Tressel (2008) \\
\hline fm_ex & Fuels and mining products as a share of total exports & $\begin{array}{l}\text { UN Comtrade Database, SITC Aggregate 2, Revision } 1 . \\
\text { For Taipei,China: Customs Administration Ministry of } \\
\text { Finance, https://portal.sw.nat.gov.tw/APGA/GA03E }\end{array}$ \\
\hline g_ck_emp & Percentage growth rate of the capital-labor ratio & Own calculations using PWT 8.1 data \\
\hline g_hc & $\begin{array}{l}\text { Percentage growth rate of index of human capital per } \\
\text { person, based on years of schooling (Barro and Lee } \\
\text { 2012) and returns to education (Psacharopoulos 1994) }\end{array}$ & Own calculations using PWT 8.1 data \\
\hline g-wap & Growth rate of working-age (15-64) population & Own calculations using WDI data \\
\hline g_wap_tr & $\begin{array}{l}\text { Trend growth rate of working-age (15-64) population, } \\
\text { obtained via the Corbae-Ourialis filter }\end{array}$ & Own calculations using WDI data \\
\hline gap100 & Technological gap variable, constructed as follows: one & Own calculations using PWT 8.1 data \\
\hline
\end{tabular}




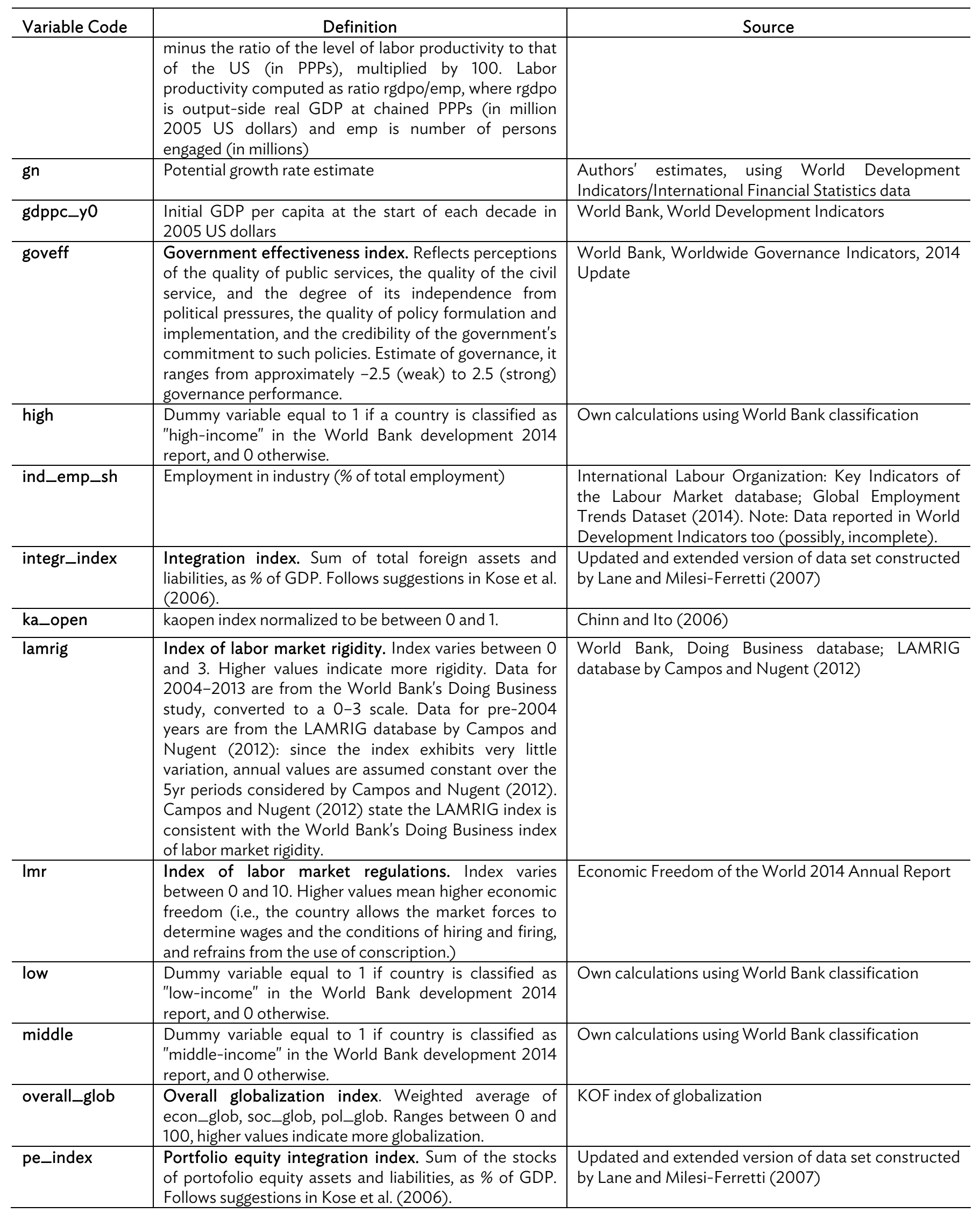


Table continued

\begin{tabular}{|c|c|c|}
\hline Variable Code & Definition & Source \\
\hline pf1corri & $\begin{array}{l}\text { Corruption perception index. Transparency } \\
\text { International Index, ranging from } 0 \text { (high corruption) to } \\
10 \text { (low corruption) }\end{array}$ & $\begin{array}{l}\text { CANA Database (v. Jan 2011) up to 2008, } \\
\text { Transparency International afterwards (plus Hong } \\
\text { Kong, China; Taipei,China; Turkmenistan). Original } \\
\text { source: Transparency International. }\end{array}$ \\
\hline polstab & $\begin{array}{l}\text { Political stability (and absence of violence/terrorism) } \\
\text { index. Reflects perceptions of the likelihood that the } \\
\text { government will be destabilized or overthrown by } \\
\text { unconstitutional or violent means, including politically } \\
\text { motivated violence and terrorism. Estimate of } \\
\text { governance, it ranges from approximately }-2.5 \text { (weak) to } \\
2.5 \text { (strong) governance performance. }\end{array}$ & $\begin{array}{l}\text { World Bank, Worldwide Governance Indicators, } 2014 \\
\text { Update }\end{array}$ \\
\hline regq & $\begin{array}{l}\text { Regulatory quality index. Reflects perceptions of the } \\
\text { ability of the government to formulate and implement } \\
\text { sound policies and regulations that permit and promote } \\
\text { private sector development. Estimate of governance, it } \\
\text { ranges from approximately }-2.5 \text { (weak) to } 2.5 \text { (strong) } \\
\text { governance performance. }\end{array}$ & $\begin{array}{l}\text { World Bank, Worldwide Governance Indicators, } 2014 \\
\text { Update }\end{array}$ \\
\hline rm_ex & Raw materials as a share of total exports & $\begin{array}{l}\text { UN Comtrade Database, SITC Aggregate 2, Revision } 1 . \\
\text { For Taipei,China: Customs Administration Ministry of } \\
\text { Finance. https://portal.sw.nat.gov.tw/APGA/GA03E }\end{array}$ \\
\hline rmfm_ex & $\begin{array}{l}\text { Sum of raw materials and fuels/mining products as a } \\
\text { share of total exports }\end{array}$ & $\begin{array}{l}\text { UN Comtrade Database, SITC Aggregate 2, Revision } 1 . \\
\text { For Taipei,China: Customs Administration Ministry of } \\
\text { Finance. https://portal.sw.nat.gov.tw/APGA/GA03E }\end{array}$ \\
\hline ser_emp_sh & Employment in services (\% of total employment). & $\begin{array}{l}\text { International Labour Organization: Key Indicators of } \\
\text { the Labour Market database; Global Employment } \\
\text { Trends Dataset (2014). Note: Data reported in World } \\
\text { Development Indicators too (possibly, incomplete) }\end{array}$ \\
\hline trade & $\begin{array}{l}\text { Index of openness. Trade is the sum of exports and } \\
\text { imports of goods and services measured as a share of } \\
\text { gross domestic product. }\end{array}$ & $\begin{array}{l}\text { World Bank, World Development Indicators, national } \\
\text { accounts data; OECD National Accounts data files. }\end{array}$ \\
\hline voa & $\begin{array}{l}\text { Voice and accountability index. Reflects perceptions } \\
\text { of the extent to which a country's citizens are able to } \\
\text { participate in selecting their government, as well as } \\
\text { freedom of expression, freedom of association, and a } \\
\text { free media. Estimate of governance, it ranges from } \\
\text { approximately }-2.5 \text { (weak) to } 2.5 \text { (strong) governance } \\
\text { performance. }\end{array}$ & $\begin{array}{l}\text { World Bank, Worldwide Governance Indicators, } 2014 \\
\text { Update }\end{array}$ \\
\hline
\end{tabular}

FDI = foreign direct investment, GDP = gross domestic product, PPP = purchasing power parity, R\&D = research and development, US = United States.

Source: Authors' compilation. 


\section{APPENDIX 3: METHODOLOGICAL NOTES ON THE ESTIMATION OF POTENTIAL OUTPUT GROWTH}

To develop the approach in estimating potential output growth, we use a formalized version of Okun's (1962) relation:

$$
U_{t}=U_{t}^{N}-\beta_{t}\left(g_{t}-g_{t}^{N}\right)
$$

where

$$
\begin{array}{ll}
U_{t} & \text { is the unemployment rate at time t } \\
U_{t}^{N} & \text { is the natural rate of unemployment at time t } \\
g_{t} & \text { is actual output growth at time t } \\
g_{t}^{N} & \text { is the growth of potential output at time t } \\
\beta_{t} & \text { is a time-varying adjustment parameter }
\end{array}
$$

Note that when the actual output growth coincides with potential output growth such that $g_{t}=g_{t}^{N}$, then $U_{t}=U_{t}^{N}$ and $\Delta U_{t}=0$. The relationship between inflation and employment is defined by the Phillip's Curve:

$$
\pi_{t}=\pi_{t}^{e}-\gamma_{t}\left(U_{t}-U_{t}^{N}\right)
$$

where $\quad \pi_{t} \quad$ is actual inflation rate at time $\mathrm{t}$

$\pi_{t}^{e} \quad$ is the expected inflation rate at time $\mathrm{t}$

Substituting (1) into (2) yield the following aggregate supply equation:

$$
\pi_{t}=\pi_{t}^{e}-\emptyset_{t}\left(g_{t}-g_{t}^{N}\right)
$$

where $\emptyset_{t}=\beta_{t} \gamma_{t}$.

Assuming rational expectations such that:

$$
\pi_{t}^{e}=\alpha_{t} \pi_{t}+\epsilon_{t}
$$

Combining this with Equation (3) yields:

$$
\pi_{t}=\alpha_{t} \pi_{t}+\emptyset_{t} g_{t}-\emptyset_{t} g_{t}^{N}+\epsilon_{t}
$$

We derive our measurement equation by rearranging the terms in Equation (5):

$$
g_{t}=g_{t}^{N}+\frac{\left(1-\alpha_{t}\right)}{\emptyset_{t}} \pi_{t}+\varepsilon_{t}
$$

We estimate Equation (6) for each country in our sample by applying the Kalman Filter on annual data from the World Bank Development Indicators and the CEIC databases to obtain estimates of $g_{t}^{N}$. 
APPENDIX 4: RESULTS OF BAYESIAN MODEL AVERAGING ANALYSES

\begin{tabular}{|c|c|c|c|c|c|c|c|c|c|c|c|c|c|c|c|c|}
\hline & \multicolumn{4}{|c|}{ Initial BMA Run } & \multicolumn{4}{|c|}{ Intermediate BMA Run 1} & \multicolumn{4}{|c|}{ Intermediate BMA Run 2} & \multicolumn{4}{|c|}{ Final BMA Run } \\
\hline & t-stat & PIP & 1-Std. E & r Bands & t-stat & PIP & 1-Std. E & or Bands & t-stat & $\mathrm{PIP}$ & 1-Std. E & ror Bands & t-stat & PIP & 1-Std. E & or Bands \\
\hline population & 3.63 & 1.00 & 0.740 & 1.303 & 3.86 & 1.00 & 0.718 & 1.220 & 3.84 & 1.00 & 0.716 & 1.220 & 2.64 & 1.00 & 0.250 & 0.556 \\
\hline $\begin{array}{l}\text { Initial GDP per } \\
\text { capita }\end{array}$ & -0.90 & 0.52 & 0.000 & 0.000 & 4.68 & 1.00 & 0.000 & 0.000 & -4.77 & 1.00 & 0.000 & 0.000 & -2.56 & 0.94 & 0.000 & 0.000 \\
\hline $\begin{array}{l}\text { Gross enrollment } \\
\text { ratio, tertiary }\end{array}$ & -2.62 & 0.95 & -0.127 & -0.057 & -1.29 & 0.71 & -0.066 & -0.008 & -1.27 & 0.70 & -0.658 & -0.008 & -4.52 & 0.78 & -0.743 & -0.153 \\
\hline $\begin{array}{l}\text { Financial } \\
\text { integration index }\end{array}$ & -0.38 & 0.18 & -0.001 & 0.001 & -0.28 & 0.12 & -0.001 & 0.000 & -0.29 & 0.12 & -0.001 & 0.000 & -0.82 & 0.48 & -0.002 & 0.000 \\
\hline $\begin{array}{l}\text { Index of trade } \\
\text { openness }\end{array}$ & 0.06 & 0.05 & -0.002 & 0.002 & 2.09 & 0.90 & 0.012 & 0.035 & 2.07 & 0.89 & 0.012 & 0.035 & 4.10 & 1.00 & 0.026 & 0.043 \\
\hline $\begin{array}{l}\text { Technology gap } \\
\text { with the US }\end{array}$ & 0.16 & 0.07 & -0.006 & 0.009 & 0.49 & 0.25 & -0.009 & 0.026 & 0.49 & 0.25 & -0.009 & 0.026 & 2.61 & 0.94 & 0.042 & 0.093 \\
\hline $\begin{array}{l}\text { Government } \\
\text { efficiency index }\end{array}$ & 0.30 & 0.12 & -0.288 & 0.538 & 3.01 & 0.97 & 1.439 & 2.870 & 2.86 & 0.96 & 1.344 & 2.787 & 2.41 & 0.93 & 1.147 & 2.777 \\
\hline $\begin{array}{l}\text { Labor market } \\
\text { rigidity index }\end{array}$ & -0.26 & 0.10 & -0.485 & 0.285 & -1.24 & 0.69 & -2.715 & -2.894 & -1.38 & 0.74 & -2.855 & -4.547 & -1.74 & 0.83 & -2.719 & -0.735 \\
\hline $\begin{array}{l}\text { Voice and } \\
\text { accountability } \\
\text { index }\end{array}$ & 3.72 & 0.99 & 2.260 & 3.923 & 0.92 & 0.54 & -0.065 & 1.629 & 0.85 & 0.49 & -0.120 & 1.490 & 1.28 & 0.70 & 0.271 & 2.224 \\
\hline $\begin{array}{l}\text { Share of agricultural } \\
\text { employment in } \\
\text { total employment }\end{array}$ & -0.10 & 0.05 & -0.012 & 0.010 & 0.09 & 0.06 & -0.009 & 0.011 & 0.10 & 0.06 & -0.009 & 0.011 & & & & \\
\hline R\&D expenditures & -0.08 & 0.05 & -0.236 & 0.202 & -0.15 & 0.07 & -0.210 & 0.156 & -0.14 & 0.07 & -0.209 & 0.156 & & & & \\
\hline $\begin{array}{l}\text { Gross enrollment } \\
\text { ratio, Primary }\end{array}$ & -0.18 & 0.07 & -0.017 & 0.119 & -0.32 & 0.14 & -0.026 & 0.013 & -0.31 & 0.14 & -0.025 & 0.013 & & & & \\
\hline $\begin{array}{l}\text { Gross enrollment } \\
\text { ratio, Secondary }\end{array}$ & 0.18 & 0.07 & -0.005 & 0.007 & 0.41 & 0.19 & -0.007 & 0.017 & 0.43 & 0.21 & -0.007 & 0.018 & & & & \\
\hline $\begin{array}{l}\text { Financial reform } \\
\text { index }\end{array}$ & 0.29 & 0.11 & -1.604 & 2.913 & 0.19 & 0.08 & -0.648 & 0.953 & 0.18 & 0.07 & -0.615 & 0.876 & & & & \\
\hline $\begin{array}{l}\text { Regulatory quality } \\
\text { index }\end{array}$ & -0.13 & 0.06 & -0.205 & 0.159 & -0.46 & 0.22 & -0.638 & 0.238 & & & & & & & & \\
\hline Rule of law index & -0.19 & 0.07 & -0.412 & 0.279 & -0.30 & 0.13 & -0.576 & 0.311 & & & & & & & & \\
\hline $\begin{array}{l}\text { Growth of the } \\
\text { capital-labor ratio }\end{array}$ & 0.26 & 0.10 & -0.008 & 0.013 & & & & & & & & & & & & \\
\hline $\begin{array}{l}\text { Growth rate of } \\
\text { human capital }\end{array}$ & 0.01 & 0.05 & -0.484 & 0.049 & & & & & & & & & & & & \\
\hline
\end{tabular}


Appendixes | 33

Table continued

\begin{tabular}{|c|c|c|c|c|c|c|c|c|c|c|}
\hline & \multicolumn{4}{|c|}{ Initial BMA Run } & \multicolumn{2}{|c|}{ Intermediate BMA Run 1} & \multicolumn{2}{|c|}{ Intermediate BMA Run 2} & \multicolumn{2}{|c|}{ Final BMA Run } \\
\hline & t-stat & PIP & 1-Std. & r Bands & t-stat $\quad$ PIP & 1-Std. Error Bands & t-stat $\quad$ PIP & 1-Std. Error Bands & t-stat PIP & 1-Std. Error Bands \\
\hline $\begin{array}{l}\text { Capital account } \\
\text { openness }\end{array}$ & 0.08 & 0.05 & -0.312 & 0.365 & & & & & & \\
\hline $\begin{array}{l}\text { Overall. } \\
\text { globalization index }\end{array}$ & 0.20 & 0.08 & -0.016 & 0.025 & & & & & & \\
\hline $\begin{array}{l}\text { Portfolio equity } \\
\text { integration index }\end{array}$ & 0.01 & 0.06 & -0.002 & 0.002 & & & & & & \\
\hline $\begin{array}{l}\text { Political stability } \\
\text { index }\end{array}$ & 0.24 & 0.09 & -0.146 & 0.240 & & & & & & \\
\hline $\begin{array}{l}\text { Share of agricultural } \\
\text { employment in } \\
\text { total employment }\end{array}$ & -0.06 & 0.05 & -0.018 & 0.016 & & & & & & \\
\hline
\end{tabular}

BMA = Bayesian Model Averaging, GDP = gross domestic product, PIP = posterior inclusion probability, R\&D = research and development, US = United States

Source: Authors' estimates. 


\section{APPENDIX 5: FIXED EFFECTS PANEL REGRESSION RESULT FOR THE BASELINE MODEL (EQUATION 4)}

\begin{tabular}{|c|c|}
\hline & All Countries \\
\hline \multirow{2}{*}{ Constant } & -.45211 \\
\hline & {$[1.4127]$} \\
\hline \multirow{2}{*}{ Initial GDP per capita } & -.00004 \\
\hline & {$[.000047]$} \\
\hline \multirow{2}{*}{ Trend growth rate of working-age population } & $1.0296^{\text {th }}$ \\
\hline & {$[.39145]$} \\
\hline \multirow{2}{*}{ Technology gap with the US } & .067824 \\
\hline & {$[.02750]$} \\
\hline \multirow{2}{*}{ Gross enrollment ratio, tertiary level } & -.04964 \\
\hline & {$[.03922]$} \\
\hline \multirow{2}{*}{ Labor market rigidity } & -1.6369 \\
\hline & {$[.64582]$} \\
\hline \multirow{2}{*}{ Index of Voice and Accountability } & $1.4685^{* *}$ \\
\hline & {$[.4622]$} \\
\hline \multirow{2}{*}{ Government efficiency } & 1.1799 \\
\hline & {$[.4808]$} \\
\hline \multirow{2}{*}{ Trade openness } & .05390 \\
\hline & {$[.01125]$} \\
\hline \multirow{2}{*}{ Financial Integration } & -.00308 \\
\hline & {$[.0005]$} \\
\hline $\mathrm{R}^{2}$ & 0.160 \\
\hline$p$-value for Ho: $\beta_{1}=1$ & 0.941 \\
\hline Number of countries ${ }^{a}$ & 61 \\
\hline Number of observations & 655 \\
\hline
\end{tabular}

GDP = gross domestic product, US = United States.

Notes: (i) ${ }^{* * *}$ - significant at $0.01 ;{ }^{* *}$ - significant at $0.05 ;^{*}$ - significant at 0.1 ; (ii) numbers in brackets are standard errors of the coefficient estimate.

a Countries included in the sample: Argentina, Australia, Austria, Azerbaijan, Bangladesh, Belgium, Bolivia, Brazil, Cambodia, Canada, People's Republic of China, Colombia, Costa Rica, Czech Republic, Denmark, Dominican Republic, Ecuador, Estonia, Finland, France, Germany, Greece, Hungary, Iceland, India, Indonesia, Ireland, Israel, Italy, Japan, Kazakhstan, Republic of Korea, Malaysia, Mexico, Morocco, The Netherlands, New Zealand, Norway, Pakistan, Panama, Peru, Philippines, Poland, Portugal, Qatar, Saudi Arabia, Singapore, Slovenia, South Africa, Spain, Sri Lanka, Sweden, Switzerland, Tajikistan, Thailand, Turkey, United Kingdom, United States, Uruguay, Uzbekistan, and Viet Nam.

Source: Authors' estimates. 
APPENDIX 6: SUMMARY STATISTICS BY INCOME CATEGORIES

\begin{tabular}{|c|c|c|c|c|c|c|c|c|c|c|}
\hline \multirow[t]{2}{*}{$\begin{array}{l}\text { Variable } \\
\text { Name }\end{array}$} & \multirow[t]{2}{*}{ Variable Definition } & \multirow[t]{2}{*}{ Units } & \multicolumn{4}{|c|}{ High-Income Countries } & \multicolumn{4}{|c|}{ Middle-Income Countries } \\
\hline & & & Mean & SD & Min & Max & Mean & SD & Min & Max \\
\hline$g n$ & Potential GDP growth & $\%$ & 3.74 & 3.17 & -8.22 & 20.06 & 5.27 & 3.07 & -5.75 & 33.96 \\
\hline \multicolumn{11}{|c|}{ Theoretical growth model variables } \\
\hline g_wap_tr & $\begin{array}{l}\text { Trend growth rate of working-age } \\
\text { population }\end{array}$ & $\%$ & 1.26 & 1.75 & -1.94 & 19.95 & 2.47 & 0.74 & -1.14 & 4.13 \\
\hline g_hc & Growth rate of human capital index & $\%$ & 0.73 & 0.63 & -2.24 & 4.59 & 1.04 & 0.73 & -1.69 & 4.52 \\
\hline di16merdt & R\&D expenditures & $\%$ of GDP & 1.48 & 0.92 & 0.01 & 4.86 & 0.33 & 0.27 & 0.00 & 1.49 \\
\hline g_ck_emp & Growth of the capital-labor ratio & $\%$ & 3.74 & 4.85 & -19.12 & 31.26 & 3.41 & 5.46 & -16.75 & 37.30 \\
\hline gap100 & Technology gap with the US & $\%$ & 34.97 & 37.00 & -336.00 & 91.00 & 81.05 & 11.88 & 41.00 & 97.00 \\
\hline \multicolumn{11}{|c|}{ Growth Convergence Variable } \\
\hline Gdppc_y0 & $\begin{array}{l}\text { Initial GDP per capita at the start of each } \\
\text { decade }\end{array}$ & In 2005 PPP US dollars & 21,618 & 14,289 & 1,107 & 81,567 & 2,078 & 1,742 & 121.19 & 8,085 \\
\hline \multicolumn{11}{|c|}{ Education variables } \\
\hline es7enrop & Gross enrollment ratio, Primary & $\begin{array}{c}\% \text { of population of the age group } \\
\text { that officially corresponds to } \\
\text { primary level }\end{array}$ & 102.22 & 7.05 & 59.18 & 128.10 & 103.21 & 15.71 & 37.95 & 154.62 \\
\hline es2enros & Gross enrollment ratio, Secondary & $\begin{array}{c}\% \text { of population of the age group } \\
\text { that officially corresponds to } \\
\text { secondary level }\end{array}$ & 94.95 & 18.36 & 24.97 & 170.95 & 62.52 & 21.26 & 15.98 & 114.74 \\
\hline es3enrot & Gross enrollment ratio, Tertiary & $\begin{array}{c}\% \text { of population of the age group } \\
\text { that officially corresponds to } \\
\text { tertiary level }\end{array}$ & 43.01 & 20.30 & 1.42 & 101.40 & 17.77 & 10.91 & 0.00 & 52.69 \\
\hline es10schom & Mean years of schooling & Years & 9.25 & 1.82 & 4.38 & 13.02 & 6.28 & 1.83 & 1.80 & 10.10 \\
\hline es12educe & Pupil expenditure on education & Expenditure & 4.99 & 1.42 & 1.39 & 9.13 & 3.79 & 1.63 & 0.89 & 9.47 \\
\hline es14teacr_ s & Primary pupil-teacher ratio & $\%$ & 17.42 & 5.87 & 6.78 & 48.09 & 28.35 & 7.63 & 11.30 & 63.00 \\
\hline \multicolumn{11}{|c|}{ Openness variables } \\
\hline overall_glob & Economic globalization index & Index $(0-100)$ & 68.82 & 14.18 & 26.87 & 92.37 & 43.14 & 13.12 & 11.77 & 79.31 \\
\hline ka_open & Capital account openness & Index (0-1) & 0.72 & 0.33 & 0.00 & 1.00 & 0.34 & 0.31 & 0.00 & 1.00 \\
\hline fin_ref & Financial reform index & Index (0-1) & 0.66 & 0.27 & 0.00 & 1.00 & 0.36 & 0.26 & 0.00 & 0.95 \\
\hline rer & Real exchange rate & Index & 0.59 & 0.37 & 0.06 & 2.17 & 0.28 & 0.17 & 0.03 & 1.36 \\
\hline trade & Index of trade openness & $\%$ of GDP & 82.26 & 70.91 & 8.93 & 455.28 & 57.14 & 38.28 & 4.98 & 220.41 \\
\hline pe_index & Portfolio equity integration index & $\%$ of GDP & 102.50 & 624.75 & 0.00 & 8238.7 & 3.67 & 8.17 & 0.00 & 71.99 \\
\hline fdi_index & FDI integration index & $\%$ of GDP & 117.81 & 604.31 & 0.00 & 9079.3 & 18.73 & 20.22 & -14.62 & 160.65 \\
\hline integr_index & Financial integration index & $\%$ of GDP & 501.58 & $2,111.29$ & 9.75 & $2,4074.9$ & 102.07 & 133.03 & 12.61 & $1,498.39$ \\
\hline \multicolumn{11}{|c|}{ Quality of institution variables } \\
\hline voa & Voice and accountability index & Standardized z-scores (-2.5-2.5) & 1.03 & 0.66 & -1.86 & 1.83 & -0.44 & 0.77 & -2.21 & 1.17 \\
\hline
\end{tabular}


36 | Appendixes

Table continued

\begin{tabular}{|c|c|c|c|c|c|c|c|c|c|c|}
\hline \multirow[t]{2}{*}{$\begin{array}{l}\text { Variable } \\
\text { Name }\end{array}$} & \multirow[t]{2}{*}{ Variable Definition } & \multirow[t]{2}{*}{ Units } & \multicolumn{4}{|c|}{ High-Income Countries } & \multicolumn{4}{|c|}{ Middle-Income Countries } \\
\hline & & & Mean & SD & Min & Max & Mean & SD & Min & Max \\
\hline polstab & Political stability index & Standardized z-scores $(-2.5-2.5)$ & 0.79 & 0.56 & -1.62 & 1.67 & -0.67 & 0.74 & -2.81 & 0.99 \\
\hline goveff & Government efficiency index & Standardized z-scores (-2.5-2.5) & 1.32 & 0.62 & -0.39 & 2.43 & -0.27 & 0.54 & -1.68 & 1.25 \\
\hline regq & Regulatory quality index & Standardized z-scores $(-2.5-2.5)$ & 1.23 & 0.56 & -0.99 & 2.25 & -0.28 & 0.66 & -2.18 & 0.83 \\
\hline rol & Rule of law index & Standardized z-scores (-2.5-2.5) & 1.24 & 0.59 & -0.83 & 2.00 & -0.48 & 0.52 & -1.69 & 0.66 \\
\hline cocorr & Control of corruption index & Standardized z-scores $(-2.5-2.5)$ & 1.32 & 0.80 & -0.69 & 2.59 & -0.50 & 0.48 & -1.50 & 0.78 \\
\hline pf1corri & Corruption perception index & Index $(0-10)$ & 6.73 & 2.12 & 1.48 & 10.00 & 3.37 & 1.10 & 0.40 & 7.67 \\
\hline Lamrig & Labor market rigidity index & Index $(0-3.5)$ & 1.43 & 0.73 & 0.00 & 3.50 & 1.68 & 0.46 & 0.60 & 2.59 \\
\hline $\operatorname{lm} r$ & & & 5.87 & 1.68 & 2.30 & 9.50 & 5.57 & 1.14 & 3.16 & 9.10 \\
\hline \multicolumn{11}{|c|}{ Economic structure variables } \\
\hline rm_ex & $\begin{array}{l}\text { Share of raw materials exports in total } \\
\text { exports }\end{array}$ & $\%$ of total exports & 19.69 & 20.95 & 1.05 & 98.57 & 33.30 & 29.01 & 0.38 & 97.69 \\
\hline fm_ex & $\begin{array}{l}\text { Share of mining and fuels exports in total } \\
\text { exports }\end{array}$ & $\%$ of total exports & 14.75 & 20.44 & 0.10 & 98.57 & 25.35 & 26.93 & 0.00 & 97.28 \\
\hline$r m f m \_e x$ & $\begin{array}{l}\text { Share of raw materials and fuels exports in } \\
\text { total exports }\end{array}$ & $\%$ of total exports & 19.69 & 20.95 & 1.05 & 98.57 & 33.30 & 29.01 & 0.38 & 97.69 \\
\hline ind_emp_sh & $\begin{array}{l}\text { Share of agricultural employment in total } \\
\text { employment }\end{array}$ & $\%$ of total employment & 27.94 & 6.68 & 11.40 & 59.60 & 20.92 & 4.99 & 8.19 & 36.40 \\
\hline ser_emp_sh & $\begin{array}{l}\text { Share of agricultural employment in total } \\
\text { employment }\end{array}$ & $\%$ of total employment & 64.91 & 9.88 & 31.40 & 88.00 & 45.03 & 14.30 & 13.10 & 79.00 \\
\hline agr_emp_sh & $\begin{array}{l}\text { Share of agricultural employment in total } \\
\text { employment }\end{array}$ & $\%$ of total employment & 6.90 & 5.95 & 0.10 & 34.20 & 36.19 & 15.17 & 4.50 & 76.13 \\
\hline
\end{tabular}

$\mathrm{FDI}=$ foreign direct investment, $\mathrm{GDP}=$ gross domestic product, $\mathrm{PPP}=$ purchasing power parity, $\mathrm{R} \& D=$ research and development, $\mathrm{SD}=$ standard deviation, $\mathrm{US}=\mathrm{United}$ States

Source: Authors' calculations. 
38 Appendixes

Table continued

\begin{tabular}{|c|c|c|c|c|c|c|c|c|c|c|c|c|}
\hline & $\begin{array}{c}\text { Social } \\
\text { Globalization }\end{array}$ & $\begin{array}{c}\text { Political } \\
\text { Globalization }\end{array}$ & $\begin{array}{c}\text { Overall } \\
\text { Globalization }\end{array}$ & $\begin{array}{l}\text { Agri Share of } \\
\text { Employment }\end{array}$ & $\begin{array}{l}\text { Technology } \\
\text { Gap with the } \\
\text { US }\end{array}$ & $\begin{array}{l}\text { Growth of } \\
\text { the Capital- } \\
\text { Labor Ratio }\end{array}$ & $\begin{array}{c}\text { Labor Market } \\
\text { Regulations }\end{array}$ & $\begin{array}{l}\text { Labor Market } \\
\text { Rigidity }\end{array}$ & $\begin{array}{c}\text { Voice and } \\
\text { Accountability }\end{array}$ & $\begin{array}{l}\text { Political } \\
\text { Stability }\end{array}$ & $\begin{array}{l}\text { Government } \\
\text { Effectiveness }\end{array}$ & $\begin{array}{l}\text { Regulatory } \\
\text { Quality }\end{array}$ \\
\hline Social globalization & 1.000 & & & & & & & & & & & \\
\hline Political globalization & 0.488 & 1.000 & & & & & & & & & & \\
\hline Overall globalization & 0.966 & 0.593 & 1.000 & & & & & & & & & \\
\hline Agri share of employment & -0.847 & -0.433 & -0.831 & 1.000 & & & & & & & & \\
\hline Technology gap with the US & -0.858 & -0.516 & -0.842 & 0.823 & 1.000 & & & & & & & \\
\hline Growth of the capital-labor & & & & & & & & & & & & \\
\hline ratio & -0.247 & -0.233 & -0.263 & 0.292 & 0.247 & 1.000 & & & & & & \\
\hline Labor market regulations & 0.151 & -0.055 & 0.101 & -0.112 & -0.134 & 0.062 & 1.000 & & & & & \\
\hline Labor market rigidity & -0.093 & -0.059 & -0.058 & 0.115 & 0.193 & 0.052 & -0.613 & 1.000 & & & & \\
\hline Voice and accountability & 0.781 & 0.604 & 0.821 & -0.788 & -0.772 & -0.360 & 0.063 & 0.001 & 1.000 & & & \\
\hline Political stability & 0.745 & 0.382 & 0.763 & -0.666 & -0.676 & -0.222 & 0.106 & -0.011 & 0.728 & 1.000 & & \\
\hline Government effectiveness & 0.904 & 0.518 & 0.907 & -0.806 & -0.872 & -0.264 & 0.174 & -0.195 & 0.831 & 0.776 & 1.000 & \\
\hline Regulatory quality & 0.874 & 0.445 & 0.885 & -0.807 & -0.817 & -0.251 & 0.192 & -0.178 & 0.848 & 0.779 & 0.938 & 1.000 \\
\hline Rule of law & 0.874 & 0.499 & 0.873 & -0.752 & -0.849 & -0.264 & 0.162 & -0.182 & 0.867 & 0.803 & 0.963 & 0.941 \\
\hline Control of corruption index & 0.871 & 0.458 & 0.867 & -0.790 & -0.834 & -0.264 & 0.158 & -0.184 & 0.840 & 0.783 & 0.966 & 0.940 \\
\hline Trade openness & 0.283 & -0.296 & 0.272 & -0.124 & -0.111 & 0.179 & 0.217 & -0.137 & -0.062 & 0.249 & 0.234 & 0.245 \\
\hline Raw materials share of & & & & & & & & & & & & \\
\hline exports & -0.016 & -0.103 & 0.024 & -0.042 & 0.111 & -0.129 & 0.023 & -0.107 & 0.188 & 0.145 & 0.095 & 0.169 \\
\hline $\begin{array}{l}\text { Fuel and minining products } \\
\text { share of exports }\end{array}$ & -0.269 & -0.275 & -0.255 & 0.186 & 0.160 & 0.127 & -0.004 & 0.108 & -0.230 & -0.141 & -0.275 & -0.275 \\
\hline $\begin{array}{l}\text { Sum of raw materials and } \\
\text { fuels/mining products }\end{array}$ & & & & & & & & & & & & \\
\hline $\begin{array}{l}\text { share of exports } \\
\text { Industry share of }\end{array}$ & -0.263 & -0.281 & -0.243 & 0.174 & 0.171 & 0.104 & 0.000 & 0.089 & -0.196 & -0.115 & -0.253 & -0.242 \\
\hline employment & 0.471 & 0.295 & 0.463 & -0.490 & -0.350 & -0.129 & -0.139 & 0.085 & 0.402 & 0.462 & 0.396 & 0.439 \\
\hline Services share of exports & 0.793 & 0.395 & 0.778 & -0.958 & -0.809 & -0.283 & 0.174 & -0.173 & 0.746 & 0.588 & 0.771 & 0.756 \\
\hline Capital account openness & 0.730 & 0.412 & 0.764 & -0.759 & -0.742 & -0.208 & 0.068 & -0.065 & 0.783 & 0.639 & 0.746 & 0.766 \\
\hline Chinn-Ito index of capital & & & & & & & & & & & & \\
\hline account openness & 0.730 & 0.412 & 0.764 & -0.759 & -0.741 & -0.208 & 0.068 & -0.066 & 0.783 & 0.639 & 0.745 & 0.766 \\
\hline Financial reforms index & 0.752 & 0.458 & 0.781 & -0.784 & -0.747 & -0.215 & 0.223 & -0.177 & 0.758 & 0.537 & 0.746 & 0.783 \\
\hline Portfolio equity integration & & & & & & & & & & & & \\
\hline $\begin{array}{l}\text { index } \\
\text { FDI index }\end{array}$ & 0.432 & $\begin{array}{l}0.08 \\
0.084\end{array}$ & $\begin{array}{l}0.575 \\
0.575\end{array}$ & $\begin{array}{l}-0.356 \\
-0.442\end{array}$ & $\begin{array}{l}-0.510 \\
-0.450\end{array}$ & $\begin{array}{r}-0.034 \\
0.105\end{array}$ & $\begin{array}{l}0.243 \\
0.332\end{array}$ & $\begin{array}{l}-0.232 \\
-0.145\end{array}$ & $\begin{array}{l}0.342 \\
0.309\end{array}$ & $\begin{array}{l}0.406 \\
0.462\end{array}$ & $\begin{array}{l}0.464 \\
0.542\end{array}$ & 0.476 \\
\hline $\begin{array}{l}\text { Financial market integration } \\
\text { index }\end{array}$ & 0.498 & 0.123 & 0.530 & -0.402 & -0.499 & 0.081 & 0.285 & -0.232 & 0.288 & 0.410 & 0.491 & 0.496 \\
\hline
\end{tabular}

continued on next page 
Appendixes | 39

Table continued

\begin{tabular}{|c|c|c|c|c|c|c|c|c|c|c|c|c|c|c|}
\hline & $\begin{array}{c}\text { Rule of } \\
\text { Law }\end{array}$ & $\begin{array}{c}\text { Control of } \\
\text { Corruption } \\
\text { Index }\end{array}$ & $\begin{array}{c}\text { Trade } \\
\text { Openness }\end{array}$ & $\begin{array}{c}\text { Raw } \\
\text { Materials } \\
\text { Share of } \\
\text { Exports }\end{array}$ & $\begin{array}{l}\text { Fuel and } \\
\text { Minining } \\
\text { Products } \\
\text { Share of } \\
\text { Exports } \\
\end{array}$ & $\begin{array}{c}\text { Sum of Raw } \\
\text { Materials and } \\
\text { Fuels/Mining } \\
\text { Products Share } \\
\text { of Exports } \\
\end{array}$ & $\begin{array}{c}\text { Industry } \\
\text { Share of } \\
\text { Employment }\end{array}$ & $\begin{array}{l}\text { Services } \\
\text { Share of } \\
\text { Exports }\end{array}$ & $\begin{array}{c}\text { Capital } \\
\text { Account } \\
\text { Openness }\end{array}$ & $\begin{array}{l}\text { Chinn-Ito } \\
\text { Index of } \\
\text { Capital } \\
\text { Account } \\
\text { Openness } \\
\end{array}$ & $\begin{array}{l}\text { Financial } \\
\text { Reforms } \\
\text { Index }\end{array}$ & $\begin{array}{c}\text { Portfolio } \\
\text { Equity } \\
\text { Integration } \\
\text { Index } \\
\end{array}$ & FDI Index & $\begin{array}{c}\text { Financial } \\
\text { Market } \\
\text { Integratior } \\
\text { Index }\end{array}$ \\
\hline Rule of law & 1.000 & & & & & & & & & & & & & \\
\hline Control of corruption & & & & & & & & & & & & & & \\
\hline index & 0.966 & 1.000 & & & & & & & & & & & & \\
\hline Trade openness & 0.184 & 0.197 & 1.000 & & & & & & & & & & & \\
\hline Raw materials share of & & & & & & & & & & & & & & \\
\hline $\begin{array}{l}\text { exports } \\
\text { Fuel and minining }\end{array}$ & 0.139 & 0.197 & -0.113 & 1.000 & & & & & & & & & & \\
\hline $\begin{array}{l}\text { products share of } \\
\text { exports }\end{array}$ & -0.272 & -0.214 & -0.107 & 0.146 & 1.000 & & & & & & & & & \\
\hline employment & 0.417 & 0.342 & 0.122 & -0.123 & -0.460 & -0.463 & 1.000 & & & & & & & \\
\hline Services share of exports & 0.703 & 0.769 & 0.092 & 0.089 & -0.047 & -0.032 & 0.229 & 1.000 & & & & & & \\
\hline Capital account openness & 0.743 & 0.745 & 0.121 & 0.083 & -0.164 & -0.147 & 0.375 & 0.725 & 1.000 & & & & & \\
\hline $\begin{array}{l}\text { Chinn-Ito index of capital } \\
\text { account openness }\end{array}$ & 0.743 & 0.744 & 0.121 & 0.083 & -0.163 & -0.146 & 0.375 & 0.725 & 1.000 & & & & & \\
\hline $\begin{array}{l}\text { account openness } \\
\text { Financial reforms index }\end{array}$ & 0.711 & 0.706 & 0.142 & 0.050 & -0.108 & -0.098 & 0.382 & 0.758 & 0.762 & 0.763 & 1.000 & & & \\
\hline Portfolio equity & & & & & & & & & & & & & & \\
\hline integration index & 0.442 & 0.436 & 0.425 & -0.162 & -0.188 & -0.206 & 0.109 & 0.356 & 0.382 & 0.382 & 0.393 & 1.000 & & \\
\hline $\begin{array}{l}\text { FDl index } \\
\text { Finandialmarket }\end{array}$ & 0.472 & 0.508 & 0.703 & -0.034 & -0.059 & -0.062 & 0.044 & 0.474 & 0.420 & 0.419 & 0.491 & 0.657 & 1.000 & \\
\hline $\begin{array}{l}\text { integration index } \\
\text { inter }\end{array}$ & 0.445 & 0.460 & 0.658 & -0.220 & -0.176 & -0.202 & 0.124 & 0.405 & 0.412 & 0.412 & 0.428 & 0.895 & 0.856 & 1.000 \\
\hline
\end{tabular}

$\mathrm{FDI}=$ foreign direct investment, $\mathrm{GDP}=$ gross domestic product, $\mathrm{R} \& \mathrm{D}=$ research and development, US = United States

ource: Authors' calculations. 


\section{REFERENCES}

Abiad, A., E. Detragiache, and T. Tressel. 2008. A New Database of Financial Reforms. IMF Working Paper 08-266. Washington, DC: International Monetary Fund.

Acemoglu, D., S. Johnson, and J. Robinson. 2001. The Colonial Origins of Comparative Development: An Empirical Investigation. American Economic Review. 91 (5). pp. 1369-401.

2005. Institutions as a Fundamental Cause of Long-Run Growth. In P. Aghion and S. Durlaff, eds. Handbook of Economic Growth Vol. IA. Elsevier B.V.

Babecky, J., and N. Campos. 2011. Does Reform Work? An Econometric Survey of the Reform-Growth Puzzle. Journal of Comparative Economics. 39 (2). pp. 140-58.

Barbieri, M., and J. Berger. 2004. Optimal Predictive Model Selection. Annals of Statistics. 32 (3). pp. 879-97.

Barro, R., and J. Lee. 2012. A New Data Set of Educational Attainment in the World, 1950-2010. http://barrolee.com/papers/Barro_Lee_Human_Capital_Update_2012April.pdf

Becker, G. S., K. M. Murphy, and R. Tamura. 1994. Human Capital, Fertility and Economic Growth. In G. S. Becker, ed. Human Capital: A Theoretical and Empirical Analysis with Special Reference to Education, 3rd Edition. The University of Chicago Press.

Campos, N., and J. Nugent. 2012. The Dynamics of the Regulation of Labor in Developing and Developed Countries since 1960. IZA Discussion Paper 6881.

Castellacci, F., and J. Natera. 2011. A New Panel Dataset for Cross-Country Analyses of National Systems, Growth and Development (CANA). Norwegian Institute of International Affairs Working Paper 783. Norway.

Chinn, M., and H. Ito. 2006. What Matters for Financial Development? Capital Controls, Institutions, and Interactions. Journal of Development Economics. 81 (1). pp. 163-92.

Ciccone, A., and M. Jarocinski. 2010. Determinants of Economic Growth: Will Data Tell? American Economic Journal: Macroeconomics. 2 (4). pp. 222-46.

De Luca, G., and J. R. Magnus. 2011. Bayesian Model Averaging and Weighted Average Least Squares: Equivariance, Stability, and Numerical Issues. The Stata Journal. 11 (4). pp. 518-44.

Domar, E. 1946. Capital Expansion, Rate of Growth and Employment. Econometrica. 14 (2). pp. 137-47.

Doppelhofer, G., and M. Weeks. 2007. Jointness of Growth Determinants. Proceedings of the CESifo Area Conference on Macro, Money and International Finance. CESifo Conference Center, Munich. 23-24 February 2007.

Driscoll, J., and A. Kraay. 1998. Consistent Covariance Matrix Estimation with Spatially Dependent Panel Data. The Review of Economics and Statistics. 80 (4). pp. 549-60. 
Easterly, W., and R. Levine. 2001. It's Not Factor Accumulation: Stylized Facts and Growth Models. The World Bank Economic Review. 15 (2). pp. 177-219.

2003. Tropics, Germs and Crops: How Endowments Influence Economic Development. Journal of Monetary Economics. 50 (1). pp. 3-29.

Ghosh, J., and A. Ghattas. 2015. Bayesian Variable Selection under Collinearity. The American Statistician. 69 (3). pp. 165-73.

Gwartney, J., R. Lawson, and J. Hall. 2014. Economic Freedom of the World (EFW) Annual Report 2014. The Fraser Institute.

Harrod, R. F. 1939. An Essay in Dynamic Theory. The Economic Journal. 49 (193). pp. 14-33.

Hoeting, J., D. Madigan, A. E. Raftery, and C. Volinsky. 1999. Bayesian Model Averaging: A Tutorial. Statistical Science. 14 (4). pp. 382-417.

Kaufmann, D., A. Kraay, and M. Mastruzzi. 2010. The Worldwide Governance Indicators: Methodology and Analytical Issues. World Bank Policy Research Working Paper No. 5430. Washington, DC: World Bank.

Kaufmann, D., A. Kraay, and P. Ziodo-Lobaton. 1999. Aggregating Governance Indicators. World Bank Policy Research Working Paper No. 2195. Washington, DC: World Bank.

Kose, M., E. Prasad, K. Rogoff, and S. Wei. 2006. Financial Globalization: A Reappraisal. International Monetary Fund Working Paper 06-189.

Lane, P., and G. Milesi-Ferretti. 2007. The External Wealth of Nations Mark II: Revised and Extended Estimates of Foreign Assets and Liabilities, 1970-2004. Journal of International Economics. 73 (2). pp. 223-50.

Law, S. H., and N. Singh. 2014. Does too much Finance Economic Growth? Journal of Banking and Finance. 41. pp. 36-44.

Leamer, E. 1978. Specification Searches. Wiley, New York.

Leon-Gonzales, R., and T. Vinagayathasan. 2013. Robust Determinants of Growth in Asian Developing Economies: A Bayesian Panel Data Model Averaging Approach. GRIPS Discussion Paper 12-12. Tokyo.

Magnus, J. R., O. Powell, and P. Prufer. 2010. A Comparison of Two Model Averaging Techniques with an Application to Growth Empirics. Journal of Econometrics. 154 (2). pp. 139-53.

Moral-Benito, E. 2012. Determinants of Economic Growth: A Bayesian Panel Data Approach. Review of Economics and Statistics.. 94 (2). pp. 566-79.

Nelson, R., and E. Phelps. 1966. Investments in Humans, Technological Diffusion and Economic Growth. American Economic Review. 56 (1). pp. 69-75. 
Okun, A. M. 1962. Potential GNP: Its Measurement and Significance. Proceedings of the Business and Economic Statistics Section, American Statistical Association. Vol. 7, pp. 89-104.

Psacharopoulos, G. 1994. Returns to Investment in Education: A global Update. World Development. 22 (9). pp. 1325-43.

Rodrik, D. 2006. Goodbye Washington Consensus, Hello Washington Confusion? A Review of the World Bank's Economic Growth in the 1990s: Learning from a Decade of Reform. Journal of Economic Literature. 44 (4). pp. 973-87.

Romer, P. M. 1994. The Origins of Endogenous Growth. The Journal of Economic Perspectives. 8 (1). pp. 3-22.

Sala-i-Martin, X. 1997. I Just Ran Two Million Regressions. American Economic Review. 87 (2) . pp. 17883.

Sala-i-Martin, X., G. Doppelhofer, and R. I. Miller. 2004. Determinants of Long Term Growth: A Bayesian Averaging of Classical Estimates (BACE) Approach. American Economic Review. 94 (4). pp. 813-35.

Solow, R. 1956. A Contribution to the Theory of Economic Growth. The Quarterly Journal of Economics, 70 (1). pp. 70-94.

Swan, T. W. 1956. Economic Growth and Capital Accumulation. Economic Record. 32 (2). pp. 334-61.

Swiss Economic Institute of Technology. KOF Index of Globalization. http://globalization.kof.ethz.ch/

World Bank. World Development Indicators. http://data.worldbank.org/data-catalog/worlddevelopment-indicators

—. Doing Business Database. http://www.doingbusiness.org/data

World Governance Indicators. http://info.worldbank.org/governance/wgi/index.aspx\#home

2005. Economic Growth in the 1990s: Learning from a Decade of Reform. Washington, DC. 


\section{The Pillars of Potential Growth and the Role of Policy: A Panel Data Approach}

The authors use Bayesian Model Averaging on panel data for 70 economies to examine the robustness of possible determinants of potential output growth. The robust determinants are subsequently used to analyze their magnitude of impact on potential output growth. Using Harrod's definition of potential output growth as the sum of labor force growth and changes in labor productivity, the authors find that the trend growth rate of working-age population is a good proxy variable for labor force growth. They also find that tertiary level education, the technology gap with the United States, labor market rigidity, trade openness, financial market integration, and the quality of institutions significantly affect potential output growth.

\section{About the Asian Development Bank}

ADB's vision is an Asia and Pacific region free of poverty. Its mission is to help its developing member countries reduce poverty and improve the quality of life of their people. Despite the region's many successes, it remains home to the majority of the world's poor. $A D B$ is committed to reducing poverty through inclusive economic growth, environmentally sustainable growth, and regional integration.

Based in Manila, ADB is owned by 67 members, including 48 from the region. Its main instruments for helping its developing member countries are policy dialogue, loans, equity investments, guarantees, grants, and technical assistance. 